\title{
WestVirginiaUniversity
}

THE RESEARCH REPOSITORY @ WVU

Graduate Theses, Dissertations, and Problem Reports

2013

\section{Remembering 1989: Post-Communist Commemorations in Berlin and Warsaw}

Kyle Jordan Meadows

West Virginia University

Follow this and additional works at: https://researchrepository.wvu.edu/etd

\section{Recommended Citation}

Meadows, Kyle Jordan, "Remembering 1989: Post-Communist Commemorations in Berlin and Warsaw" (2013). Graduate Theses, Dissertations, and Problem Reports. 250.

https://researchrepository.wvu.edu/etd/250

This Thesis is protected by copyright and/or related rights. It has been brought to you by the The Research Repository @ WVU with permission from the rights-holder(s). You are free to use this Thesis in any way that is permitted by the copyright and related rights legislation that applies to your use. For other uses you must obtain permission from the rights-holder(s) directly, unless additional rights are indicated by a Creative Commons license in the record and/ or on the work itself. This Thesis has been accepted for inclusion in WVU Graduate Theses, Dissertations, and Problem Reports collection by an authorized administrator of The Research Repository @ WVU. For more information, please contact researchrepository@mail.wvu.edu. 
Remembering 1989: Post-Communist Commemorations in Berlin and Warsaw

\author{
Kyle Jordan Meadows \\ Thesis submitted to the \\ Eberly College of Arts and Science \\ at West Virginia University \\ in partial fulfillment of the requirements \\ for the degree of
}
Master of Arts
in
History
Robert Blobaum, Ph.D, Chair
Joshua Arthurs, Ph.D.
Elizabeth Fones-Wolf, Ph.D.

Department of History
Morgantown, West Virginia
2013

Keywords: Commemorations; East-Central European History; Modern History; International Relations; Post-Communism; Memory Politics 


\section{ABSTRACT \\ Remembering 1989: Post-Communist Commemorations in Berlin and Warsaw}

Kyle Jordan Meadows

Germany and Poland since 1989 have become lands of contested memory, as reflected by their attempts to commemorate the series of reforms that led to the end of their Communist regimes. This study is an attempt to analyze the various modes of commemoration dedicated to the transition from communism that have taken place in the intervening years between 1989 and the present. Included amongst these efforts are events occurring in public spaces, such as official remembrance ceremonies like Berlin's Festival of Freedom in 2009, physical monuments, and institutions dedicated to preserving memory, specifically the Gauck Authority in Germany and the Institute of National Remembrance in Poland. An evaluation of the various forms that commemorations may take demonstrates the pluralities of memory in Germany and Poland, and how political factions have used this malleable state of memory to construct popular narratives. The most common narrative that has been seized upon by right-wing factions in both countries, and which has been supported by the official state memory institutions, is the false demographic separation of Communist era Germany and Poland into lands comprised solely of victims, perpetrators, and collaborators. Despite the major differences in their transitional processes, Germany and Poland followed similar trajectories in their commemorative paths, beginning with an initial period of little commemorative effort in favor of a national focus on political and economic development. After a period in which both countries saw similar major shifts in their national governments, the opening decade of the current century saw a resurgence of right-wing politics which brought about the aforementioned focus on memory. The recent focus on memory and commemoration attests to the fact that only now is the transitional period coming to a close, as younger generations with little to no personal memory of 1989 have begun to receive higher education and enter the workforce. Likewise, by studying Germany and Poland in particular, two countries with contrasting transitional experiences yet similar tracks in post-transition memory development, it is shown that there is likely a pattern to how the former Communist bloc countries that experienced peaceful reforms have remembered their post-transition experiences, and that this has negatively impacted the political landscape. 
Table of Contents

Abstract..................................................... i

Table of Contents............................................ii

1. Introduction...........................................1

2. Chapter One: Berlin Remembers......................8

A. Background....................................8

B. Commemorations...................................18

3. Chapter Two: Warsaw Remembers...................41

A. Background $. . . \ldots \ldots \ldots \ldots \ldots \ldots \ldots \ldots \ldots \ldots \ldots \ldots \ldots . . .41$

B. Commemorations...............................51

4. Conclusions...........................................73

5. Bibliography.........................................81 


\section{Introduction}

For central and eastern Europe, 1989 was perhaps the most defining year of the last quarter-century. That year marked the beginning of the end of the Cold War, with revolutions sweeping through the Communist bloc in a wave of public demand for free and fair elections, the end of Soviet meddling in domestic and foreign policy, and changes to crumbling economic infrastructures. The wave of reforms began in Poland, where years of activism by Solidarity and other interest groups succeeded in bringing Communist reformers to the Round Table Negotiations, the first event of its kind, and subsequently the first semi-free elections of the European communist countries. At its climax, 1989 saw the end of the Berlin Wall, the physical reminder of the division of Europe that had kept East Berlin shuttered to the West for over twenty years. The sudden end to the wall was seen around the world on television and in newspapers, and was greeted by the cheering crowds in Berlin as the end of an era.

Two decades later, the world still remembers 1989 as a seminal event in modern human history. The intervening time has seen a cavalcade of literature, film, and popular art commemorating the tumultuous year that heralded the beginning of the end of Communism in Europe. By augmenting the public consciousness with a multitude of commemorations and memorials, a collision between collective memory and personal memory became inevitable. What is at issue is the process by which commemorations of a transformative event in a nation's history reformulate or repurpose meaning from that event, resulting in a change to collective memory.

In order to determine the capabilities of a commemorative event as an agent in shaping collective and individual memories, one may look to Poland and Germany as 
prime examples. The importance of these two countries in this study is critical because of their contemporary importance within the Communist bloc in 1989, their current importance within Europe, and the significance of their histories in Europe in the period preceding 1989 as well as the era preceding the Communist takeover. Poland's history as a partitioned territory, followed by its brief life as an independent state, the subsequent collapse of Polish independence during German and Soviet occupations, and its eventual development as a communist country, are all massive historical markers that would play a great part in shaping Polish understanding of its role in 1989. While Germany's history follows a different path, it nonetheless draws on its turbulent and militaristic past in reconciling its tumultuous unification process, its involvement as antagonist in two world wars, its bitter separation into two distinct countries until peaceful reunification following 1989, and its status as an economic powerhouse in the post-Cold War world. A comparison of Germany and Poland will reveal that despite the differences that former communist countries faced in their transitions to democracy, the processes begun by peaceful reforms allowed for a common set of commemorative practices that may have been present throughout the former Communist Bloc.

By understanding the steps that Poles and Germans have taken to remember 1989, at both the private and public level, it will be possible to define a specific motive behind commemorations. It will be clear that commemorations do not occur organically, but are instead a calculated effort to remember a shared past outside of the bonds of personal memory. In so doing, it becomes clear that commemorations occur most frequently during times of deep national division, and are an attempt to impose ideologies on the 
past as befits actors within the present. ${ }^{1}$ The most clear-cut examples of this which will be discussed are that of Alexandra Hildebrandt's Freiheitsmahnmal (Freedom Monument) in Berlin and the use of the Institute of National Remembrance (IPN) as a political tool by the Freedom and Justice party (PiS) in Poland. Crucial to this undertaking are the unique similarities shared by the examples. Both were backed by right-wing political movements and came to prominence in 2005 , after a period of leftwing leadership in the government, both were highly controversial, and both grew as part of a response to the perceived failure on the part of the national government to properly recognize victimization at the hands of Communists. ${ }^{2}$

This study will be undertaken in a threefold manner. First, major specific examples of how Germany and Poland have commemorated 1989, both publicly and privately, will be documented. Doing so will help to further the second purpose, which is to illuminate the changing faces of national identity over time. Even though only a little more than two decades have passed since 1989, unmistakable changes in how Poland and Germany choose to commemorate can be readily identified. Finally, the third step in the process is to use these commemorations as a starting point in determining how nostalgia, remembering, and the collective memory can be implemented as tools in reshaping the way the public interprets history.

\footnotetext{
${ }^{1}$ Radoslaw Poczykowski, "Building The Past, Forgetting The Future: Is Poland A Historical Knowledge Based Society?." Limes 1, no. 1 (June 2008): 25-26. Explaining the late flurry of activity in commemorations in Poland, Poczykowski speculates, "This return to the past might be viewed as the answer to the serious political, cultural, and social crisis."

${ }^{2}$ As will be discussed, the Polish government created the IPN in 1997; however, its period of heightened controversial activity began in 2005 with the election of the Kaczynski brothers to the Presidency and office of the Prime Minister.
} 
An analytical inquiry into commemorative efforts of Germany and Poland will reveal new insights into how 1989 transformed those countries, politically, economically, and culturally. Furthermore, and perhaps more importantly, an argument can be made that commemorations not only reveal transformative processes, but are in fact catalysts for transformation in their own right.

Documenting the changes in Poland and Germany since 1989 serves a basic historical function, to be sure, but it will also show how Poles and Germans remember their recent history, history in which they also served as actors. It will show what they remember, what they choose to forget, and the importance it played in their lives at the time, as well as what importance they have ascribed to it over time. Hopefully, this study will demonstrate how societies, following a tremendous transformative event, use that transformation to progress as a people, how it affects their consciousness, and how it can change their sense of national identity.

Integral to the discussion of any form of commemoration is the concept of collective memory. How societies choose to remember, what they remember, and why they remember is a process that offers no end of complications. Collective memory as a staple of national identity is an idea that has existed for decades, but has gained significant traction since Maurice Halbwachs first delved into the "social sources of memory" in $1925{ }^{3}$ However, while that theory has been widely accepted, arguments persist that challenge a general theory of collective memory. As Susan Pearce has claimed, "the mnemonic image of the nation...may not ever be fully collective."4

\footnotetext{
${ }^{3}$ Susan Pearce, Solidarity in Retrospect, 161.

${ }^{4}$ Ibid, 162.
} 
That social memory is of paramount importance in the formation of modern nations has become a norm within the field of memory history. What debate exists centers around which social factors are most important in shaping collective memory, and more semantically, whether collective memory is in fact achievable. The quote from Pearce is indicative of the fact that there are some scholars who maintain that it is impossible to achieve a fully collective memory, because there are too many sub-groups within national cultures, and counter cultures as well, each with its own particular memory. For instance, if a collection of sub-groups were to form a consensus memory, then it is possible this could become the dominate popular national memory; however, it is again possible to have conflict between popular and political memory. Even within a society that may have a dominant national memory, there can still be a large faction that promotes its own dissent memory. An example of this scenario can be found in Poland after the election of the PiS government, where right-wing memory of the end of Communism conflicted with the previous transition narrative put forth by Solidarity and its allies. Yet with the rise of the right-wing Law and Justice government, dissent memory became the dominant political memory, asserting that there was a popular outcry of support for the belief that there had not been enough of a break with Communism. This belief led to the formation of some the former Communist bloc's toughest lustration policies, enacted eighteen years after the 1989 contested elections. Along with this change in memory came the co-opted usage of the formerly non-partisan IPN as the central tool for lustration.

One proposed basis of memory and identity formation is the postulation that personal memories can overlap one another, and on a large scale may codify into a 
patchwork resulting in collective memory. Halbwachs offers several examples to further explain this presumption, one of them being a comparison between a schoolteacher and a student. ${ }^{5}$ The teacher could remember having at one point taught a class, though they have no specific memories of students' names, faces, or curriculum. The student, meanwhile, informs the teacher's memory by filling in the gaps, since the student does have specific recollections of the class. Through this exchange, the teacher's memory is supported by someone else's recollections. Halbwachs asserts that this process is constantly active in all societies. Expanded to the national level, it would explain how Germans and Poles who lived through 1989 remember particularly poignant events though they did not witness them personally. The gaps in an individual's memory are filled in by the recollections of others.

Trouillot offers another, similar example of personal memory. In it, he argues that one may remember how to tie a shoe, even though one may not "engage in an explicit recall of images every time we routinely tie our shoes." ${ }^{, 6}$ The underlying presumption beneath both of these premises is the issue that while personal memory exists within everybody, it can be reshaped over time to incorporate multiple experiences, each different in its own right, but each related to the primary memory in such a way that they create a bank of knowledge augmenting the initial experience. To Halbwachs's point, on a larger scale this knowledge bank can be added to by the experiences of others, which is the foundation of memory or identity formation.

\footnotetext{
${ }^{5}$ Maurice Halbwachs, The Collective Memory, (New York: Harper \& Row. 1980), 51. ${ }^{6}$ Michel-Rolph Trouillot, Silencing the Past: Power and the Production of History, (Boston: Beacon Press, 1995), 14.
} 
Halbwachs's original premise rests in the fact that, regardless of the patchwork nature of the social sources of memory, historical truths still exist within collective memory. More current historians have challenged this assumption. Michel-Rolph Trouillot concurs with Halbwachs's assessment of the social sources of memory; however, Trouillot differs with Halbwachs in the belief that any sort of fundamental truth can result from collective memory. This is not to say that Trouillot asserts that there can be no truths in history. Obviously, in order for there to be a present, there had to be a past, and Trouillot's similar analogy to Halbwachs's teacher-student exercise demonstrates this. What Trouillot really claims is that history and narrative are necessarily inseparable.

Within Trouillot's argument is the assertion that any one historical event can have multiple narratives. This is not just because every individual remembers events differently; rather, it is because any group must have a basis in a historical past to validate its existence. Historical narratives are socially constructed despite the fact that individuals may have conflicting personal memories. These contradictions are the most curious and also the most telling aspects of collective memory, because an individual may be compelled to wholeheartedly accept a consensus memory even when his own individual recollections are at odds with the historical narratives.

Trouillot further postulates that the focal points for collective memory are the silences of history. The inability of historical truths to speak for themselves leaves social groups to speak for them. Therefore, in the creation of collective memory, silences from the past can be forgotten or glossed over, in favor of those recollections more useful for the place and time. This explains how the meaning of a shared past can change within 
one culture over time, or how contemporary groups can remember the same event so vastly differently.

This discussion points out the inherent complications in trying to understand collective memory. There is no right or wrong way to remember, and each group will choose its own understanding of the past. Memory can occur from the top down, meaning that it is focused on events occurring at the top levels of society and government, moving down to the broader societal levels. Conversely, memory can be focused on the bottom up, progressing from popular movements up to the leadership level. Memory is also affected by space, which will be seen in great detail in the case of Berlin. This study will attempt to show how Germany and Poland have dealt with memory in the context of their transitions to democracy, and how their relationship to the past has informed their understanding of the present. It will highlight not only their differences, but also their similarities, and will highlight how those similarities have created a common commemorative landscape. 


\section{Berlin Remembers}

\section{A. Background}

Commemorative activities in post-1989 Germany are a mixture of privately and publicly funded. It is necessary to draw a distinction between private and public memorials because there are differences between the two that separate them beyond the source from which they draw their funds. Having a collection of private and public commemorative spaces is by no means exclusive to Germany; rather, it is a state of being familiar to most countries. Germany's predicament is unique because it requires both private and public commemorations to directly confront one another by navigating a level of historical overlap not seen in most modern states. The juxtaposition of private versus public commemorations and historical overlap are the two themes that have most shaped the trajectory of German commemorations of 1989.

Regarding the struggle between private and public memorials, there have been some prime examples within the last decade alone that articulate both the differences between the two types and the methods by which one may impact the other. In the most recent notable instance, that of the Freiheitsmahnmal in 2005, which will be discussed in greater detail, it can be seen that the special interests of some private memorials reach a level of such notoriety that they are adopted into use by official memorials. Conversely, the failure of a public memorial or event to address a specific issue can spark the creation of a private memorial with a special interest at its heart. Both of these themes have been major issues impacting the development of German commemorations of 1989. 
Another major feature of German commemorations is the theme of overlap. Germany's modern history is by no means secret, and its notorious role in the Holocaust and Second World War has had an indelible impact on the modern German nation, to state the case mildly. This history is especially apparent in Berlin, where the political center of Nazi power and the front line of the Cold War shared the same space. With the weight of that history upon it, perhaps it is not surprising that one of the most popular ways to remember the past in Berlin has been to intentionally draw parallels between the two eras. Physical examples of this are prevalent throughout the city, nowhere more evident than at the Brandenburg Gate and the Topography of Terror. The Brandenburg Gate was utilized by the Nazis as a powerful symbol of German militaristic nationalism during the fascist period, and was the scene of spectacular rallies. Conversely, the gate played a sad role during the Cold War period as an abandoned monument, cut off from Berliners by the Berlin Wall. The Topography of Terror, which encompasses a former Gestapo prison and the offices of Adolf Eichmann, among other grisly Nazi relics, is bordered in part by remnants of the Berlin Wall. ${ }^{7}$ These prove that historical overlap, a theme critical to understanding how Germany remembers its experience in 1989, most often finds its physical roots in one of Berlin's most significant landmarks, the Berlin Wall.

The Berlin Wall is arguably the greatest symbol of the Cold War. As the physical manifestation of Churchill's "Iron Curtain," the only thing more sudden and unforeseen than its construction was its destruction. After nearly three decades of dividing one city

\footnotetext{
${ }^{7}$ Iwona Irwin-Zarecka, "'Topography of Terror' in Berlin: Is remembrance of forgetting possible?" Journal Of Arts Management, Law \& Society 25, no. 1 (Spring 1995): 17.
} 
through its heart, in just one night the wall became irrelevant. Many of the German commemorations of 1989 have focused on events directly related to or impacted by the wall, so it is necessary to pay attention to the wall's legacy by understanding what the wall represented during its existence, and what it has meant since its collapse.

Construction of the wall began on August 13, 1961, when "East German police officers and soldiers begin barricading the Eastern sector of Berlin from the three Western sectors, preventing any further migration." 8 By August $26^{\text {th }}$, the wall was complete, stemming a flood of East Germans escaping into West Germany, and effectively sealing off Berlin from the West. At the same time, border controls were tightened across the entire East German frontier. Almost overnight, small towns that had once been in the heart of Germany suddenly became border towns. Such was the case of Kella, a town in the Catholic Eichsfeld region of Germany, where residents had been unable to attend mass at their local church for decades when it became impossible for them to cross the newly impenetrable border into the neighboring village. ${ }^{9}$

And so the wall remained for twenty-eight years, scarring the very heart of Berlin. The wall is physically absent now, but even in its absence there are reminders of its existence, not only in the form of monuments and commemorative events, but in the hearts and minds of Berliners and Germans who lived on either side of the Iron Curtain.

\footnotetext{
8 "Berlin Divided...And Reunited: 1961-1989," The Berlin Wall: Twenty Years Later, George Clack, ed. (Washington, D.C.: U.S. Department of State, Bureau of International Information Programs, 2009): 23. http://www.america.gov/publications/books/berlin_wall.html ${ }^{9}$ Daphne Berdahl, Where the World Ended: Re-Unification and Identity in the German Borderland (Berkeley: University of California Press, 1999).
} 
The wall continues to divide how Ossis and Wessis remember their history, and how they are shaping their future.

The end of the Berlin Wall came about suddenly, with no notice given to either side. November 9, 1989 saw West German Chancellor Helmut Kohl in a delicate situation. As scheduled, Kohl spent the day in Warsaw, meeting with leaders from both sides of the Polish political spectrum to discuss the new relationship that the FRG and Poland would have to build. ${ }^{10}$ In the course of the day, Kohl was interrupted by the unexpected news that events in Berlin were taking a wild and unprecedented turn. Kohl realized that he would have to fly to Germany as quickly as possible, since it was his duty as chancellor to be in Germany should anything of such magnitude occur, and of course the announcement by Gunter Schabowksi of the GDR's decision to open the gates dividing West and East Germany was of unparalleled significance. Kohl excused himself as politely as he could from his Polish obligations, to the annoyance of many Poles he was scheduled to meet with, and flew back to Bonn, the West German capital, before being flown to Berlin. ${ }^{11}$

On November 10, standing in front of a hostile crowd of West Berliners, Kohl declared in a speech, "I would like to call out to everyone in the GDR: You are not alone!

${ }^{10}$ Mary Elise Sarotte, 1989: The Struggle to Create Post-Cold War Europe, (Princeton: Princeton University Press, 2009). 50-52. The change of government in Poland had brought with it concerns over the post-World War II Polish-German border. Kohl was in Warsaw to shore up relations with the new government, and to offer assurances of no new change in frontier policy on the German side. The Poles were miffed by Kohl's hasty departure, but the issue would soon be settled permanently as a result of the $2+4$ process.

${ }^{11}$ Ibid., 52. Despite its close proximity to the Polish border, Kohl had to make this roundabout trip because West German aircraft were still denied landing clearance in Berlin. Kohl actually flew to Berlin in a non-German, third party aircraft. 
We stand at your side! We are and will remain one nation, and we belong together!"12 The audience soundly booed him. The mayor of West Berlin, Walter Momper, not a member of Kohl's more conservative Christian Democrats, declared that Kohl had not taken the pulse of the people, that, "he's stuck in yesterday's thinking."13 He did not realize that unification was the dream of an older, more conservative generation. The younger, liberal Germans, especially Berliners, were far more interested in a free European state. ${ }^{14}$ Many East Berliners felt the same as their counterparts. A unified Germany was a secondary issue for many people. Most important was to have a Europe with open borders and free movement of people, with full cooperation between all European states. What need would there be for a unified Germany in such a system? It could only be a hindrance, especially considering that the two states varied greatly in their social and economic systems. Incorporating one state into another would mean completely changing the way of life for millions of people in the GDR, possibly removing some of the benefits that they may have actually enjoyed in a socialized state. True, East German life was difficult, and the massive state security apparatus vigilantly upheld repressive measures, but that does not mean that all East Germans were totally opposed to the fundamental values of the underlying system. Most East Germans hated the government of the GDR, but they did not hate socialism. There was a hope that they could maintain elements of a socialist state that would continue to provide benefits to workers, while implementing a fully democratic, multi-party electoral process.

\footnotetext{
${ }^{12}$ Ibid, 53

${ }^{13}$ Ibid, 53.

${ }^{14}$ Ibid, 53.
} 
Articles from 1999 support this idea. Nearly a decade after unification, unemployment in former East Germany was more than double that of the west. Data from the Federal Statistics Office put the unemployment rate in the former GDR at $17.2 \%$, compared to $8.3 \%$ in the former FRG; likewise, there was an equally large gap in GDP per capita, at only $\$ 15,632$ in Eastern Germany compared to $\$ 27,887$ in Western Germany. ${ }^{15}$ It can be said that those capable of finding employment in the east were still making more money than they had in the GDR, however, they did not have the social safety nets in the new unified Germany that they had enjoyed previously. Barbara Lassig, one such East German, became the owner of her apartment building after the wall fell. ${ }^{16}$ While she now had opportunities that she could not have had in the GDR, she said that she was forced to deal with a market she had never faced under socialism. She had to cut more than half her employees in just one year, and constantly faced trouble paying her mortgage. She looked back fondly at her life in the GDR, where she taught physical education to kindergarten classes. Unfortunately, she could not keep that job in the new Germany, as the federal government did not provide economic support for that position. ${ }^{17}$

1999 saw a Germany that was still facing an identity crisis. It had to deal with two halves that had developed different economic and social systems over the previous forty years, and was forced to confront the problems of a large sector of the population characterized by growing discontent and resentment towards the new system. Many easterners were angered at the "political arrogance" displayed by the west in unification, and many westerners were upset by the amount of support they had given to the east

15 Jack Ewing, “A Nation Still Divided,” BusinessWeek, (November 8, 1999), 70.

16 Ibid.

17 Ibid. 
without receiving their due appreciation. ${ }^{18}$ Perhaps this is why much of the focus in 1999 was in looking towards the future. Looking at the past could often only bring resentment, especially in a country like Germany, which had faced such a tumultuous twentieth century. Instead, with unification now a fact of life, the federal government and the German states began looking ahead to create a new Germany based more on panEuropean ideals, rather than trying to recreate a Germany based on the past. With this attitude, the federal government made a hugely symbolic move in 1999 by abandoning its longtime seat in Bonn and making the newly unified city of Berlin the capital of the newly unified Germany.

The official commemoration in 1999 was very unlike its successor in 2009. Whereas 2009 would feature a stunning drama unfold in a stacked line of dominos, with music and revelers filling the streets, 1999 was an altogether bleaker affair, reflecting the pensive attitude Germans had over their present and past. Looking on from a distance, television audiences might have seen a fairly boisterous crowd, but in reality November 9, 1999 was a political spectacle, and a largely unimpressive one. On the ground in Berlin, Timothy Garton Ash reflected that, "ten years on, the celebration is a purely political and media event...the scenes from 1989 have been replayed so many times on television that they have lost their impact." ${ }^{19}$ A crowd gathered in front of the Brandenburg Gate for the television cameras in order to create the illusion of drama, which of course the event was really lacking. In reality, most people remained at home on this rainy night. Television had relayed the news of November 9, 1989 to the world, just

\footnotetext{
18 "Not Quite Grown Up," Economist, (November 7, 2009), 24.

${ }^{19}$ Timothy Garton Ash, History of the Present: Essays, Sketches, and Dispatches from Europe in the 1990s (New York: Random House, 1999), 350.
} 
as now, ten years later, television was attempting to recreate a drama that was no longer there. So television created a story that did not exist, and that story was then told around the world. "The anniversary of the ultimate modern event," says Garton Ash, "is marked by the ultimate postmodern event."20

If 1999 saw reluctant Germans trying to look ahead, to move away from their checkered past and escape the realities of the hardships that followed unification, 2009 saw Germans triumphant. By comparison, Germany was doing much better in 2009 than it was in 1999. The economy was in a much better shape, which goes a long way in helping to improve any country's attitude, and the hardships of reunification, and of life in the former GDR itself, was beginning to fade, in large part due to the aging of the first post-communist generation. As the younger generation continues to age, the national memory of 1989 will continue to shift. Since this new generation has no memory of communism, dictatorship, or division, it cannot incorporate those things into its collective consciousness based on personal memories. It must therefore learn 1989 on its own terms, stripping important events of their original meaning and replacing them with something more comprehensible. The events that they will uncover are still in the process of being interpreted by a generation that lived through the transition. Through the use of memorials, commemorative sites and spectacles, art installations, and federal archives, Germans are collectively reshaping their identity. What they will leave to later generations to interpret is the way in which they wish themselves to be perceived. Initially, this view was nuanced, with an emphasis placed on coping with the realities of everyday life, but over time it has morphed into something simpler and more easily

\footnotetext{
${ }^{20}$ Ibid.
} 
defined. The narrative of victims and perpetrators has largely taken over German memories of Communism, through gradual shifts in thought at the public and private level. 


\section{B. Commemorations}

One theory of memory formation claims that memory is rooted in a sense of place, and nowhere in the former Communist states is this more evident than in Berlin. Littered with remnants from a tragic past, Berlin typifies the notion that "a sense of place...is inextricably linked to memory formation, which is, of course, crucial to identity formation, both at the individual and collective levels. ${ }^{21}$ Sifting through the sites connected to memory in Berlin is an exercise in cultural self-awareness. One is never far from a space connected to the terrors of multiple bygone eras, often overlapping one another.

How Berliners navigate their historical places, or how they choose to commemorate, is reflective of how they have shaped their identity as a unified city in a unified country. Choosing what to commemorate and what to leave alone or tear down is indicative of a choice between what to remember and what to forget. This aspect of memory formation is unavoidable. They could choose to commemorate everything, or they could choose to commemorate nothing, but at some point a choice has to be made by one agency or another, and in this decision is the foundation of memory formation.

The official twentieth anniversary celebration of the fall of the Berlin Wall in 2009 culminated with an impressive array of massive dominoes. Acting as the climactic event of the "Festival of Freedom," the dominoes were arranged in a line following the path of the original Berlin Wall, symbolizing both the physical wall and the chainreaction of events in 1989 that ultimately led to the end of the Soviet Union in 1991, a

\footnotetext{
${ }^{21}$ Margarert E. Farrar. "Amnesia, Nostalgia, and the Politics of Place Memory," Political Research Quarterly, 64, no. 23. August 16, 2010. 725.
} 
series of events that is often referred to as the "domino effect." A party atmosphere pervaded the day, with Germans from multiple generations, including those who had lived through the entire span of the GDR and World War II and those who grew up after the wall had already been torn down, reveling in music filled streets and watching as former Polish president Lech Walesa pushed over the first domino. ${ }^{22}$

The jovial celebration at the domino wall is intentionally reminiscent of the first moments when the real wall began to fall, and in large part seems as if it was trying to recapture the same sense of unity and unrestrained joy. By intentionally mimicking the revolutionary events of 1989 on a macro scale, event organizers managed to remind attendees of emotions and hopes that had prevailed in the same space twenty years before; amongst these were hope following the end of forty years of repression, for one, and the chance of reuniting with loved ones and fellow countrymen who had been trapped on either side of the Iron Curtain. In a larger context, the celebration also served as a literal demonstration of how events within the Eastern Bloc unfolded that year. Lech Walesa, the hero of the Solidarity movement and the Round Table negotiations, pushed over the first domino representing Poland. Following that, according to the narrative of the event, it was inevitable that the other dominoes, Hungary, East Germany, Czechoslovakia, Bulgaria, the Baltic republics, and so on, would all fall in their turn. The dominoes themselves, 1000 in total, were hand-painted by thousands of children from around the world, a generation born after communism, whose only

\footnotetext{
22 “Berlin Celebrates $20^{\text {th }}$ Anniversary of Wall's Fall." NPR. November 9, 2009. http://www.npr.org/templates/story/story.php?storyid=120251023
} 
experience of the Berlin Wall comes in the form of stories from their parents or grandparents, or in lessons in primary school. ${ }^{23}$

The goal was to remind the world and its leaders that walls, both physical and political, still exist across the globe, but with seemingly one push, they, too, can fall. In an overtly symbolic gesture, the last remaining domino, which failed to collapse, was covered in Chinese symbols. Appearances by heads of state and other dignitaries from around the world elicit the feeling that not just the former Communist countries, but indeed the whole world, wanted to see the end of repressive rule in Central and Eastern Europe. The ceremony itself was evocative of the standard narrative of 1989; that is, that after one successful revolution, the stage was inevitably set for others.

While the domino ceremony emotionally recaptured what happened in November 1989 , absent was the reason for why that happened, and of the wall's lasting repercussions. The long-term impact of reunification was not to be seen or felt as the dominoes fell. For many years after the wall fell, East Germans felt alienated living in their new country. The issue of how to approach the subject of division was and is a sore one that impacted not only the adults who lived through the change, but also the children who are learning a still malleable national history.

German economic successes since 1999 have begun to blur some aspects of the troubles of reunification, and many German schoolchildren, who were born after reunification, are still not fully aware of the significance that forty years of division had on Germany. The very dominos that played a seminal role in the 2009 commemoration were painted by hundreds of school children from around the world, a generation born

23 "Berlin Wall 20" Anniversary." CBS. November 9, 2009. http://www.youtube.com/watch?v=KiZScTuwBZ0 
after communism, whose only experience of the Berlin Wall comes in the form of stories from their parents or grandparents, or in lessons in primary school. ${ }^{24}$ Amongst those children, few grasp the full nature of the wall. That year, a survey was conducted of 16 and 17-year-old schoolchildren from Berlin. According to the survey, "66 percent ... didn't consider the GDR a dictatorship." 25 Clearly there is some kind of disconnect in Germany, if a sizeable percentage of students is unaware of one of the most negative aspects of the GDR. It is difficult to determine what exactly is the cause of this. In part, it may be a sign that nostalgia for the GDR is growing, rooted in the loss of some social benefits that had been provided by the East German state.

Another possible reason behind that disconnect is the possibility that only in the present is Germany becoming truly united. It may be true that for adults who lived during the time of division, emotional and mental unification may never be completely possible. It is only with the coming of age of this younger generation that real unification will be possible. As several authors have speculated, "Keeping in mind that life courses unfold as cumulative processes, one can easily derive that the unification of the two Germanies will be concluded not before the first post-transformation cohorts will have entered school, training, and the labor market."26

As oppressive as their state may have been, many East Germans lived a major portion of their formative years and adult lives in the GDR, and therefore recognized it as

\footnotetext{
24 “Berlin Wall 20 ${ }^{\text {th }}$ Anniversary." CBS. November 9, 2009. http://www.youtube.com/watch?v=KiZScTuwBZ0

${ }^{25}$ Isabelle de Pommereau, "German children: What do they know about the Berlin Wall?," Christian Science Monitor, (November 10, 2009), 6.

${ }^{26}$ Martin Diewald, Anne Goedicke, and Karl Ulrich Mayer, After the Fall of the Wall: Life Courses in the Transformation of East Germany. (Stanford: Stanford University Press, 2006). 296.
} 
a legitimate state. Displeasure with the ruling party and the nature of authoritarian rule did not necessarily mean that East Germans were unhappy with some of the benefits afforded to them, including in many cases guaranteed state employment. After reunification, the bulk of these jobs ceased to exist. The entrance into a new, well established economic system left newly unemployed East Germans in a tenuous state where they had fewer savings and less opportunity than their West German countrymen. These problems were never fully rectified, and were a constant source of tension for most of the 1990s. Even in the most recent decade, the failure of some East German states to catch up to the West could be felt in the formation of shockingly successful neo-Nazi groups. ${ }^{27}$

Also possible is the failure of teachers to effectively communicate with students. There are still history teachers who once taught in East Germany and who have had a difficult time in revising the narrative of that state since reunification. ${ }^{28}$ Whatever the case may be, it is becoming clearer with time that the narrative of the wall and reunification is increasingly at odds with historical interpretation. As time passes, and East Germans continue to catch up to their West German counterparts in terms of income equality and standards of living, it is possible that this narrative will continue to be muddled. ${ }^{29}$

The Festival of Freedom in 2009, which espouses the Western (particularly American) view of the Cold War, depicts a land of victims and perpetrators in the East

\footnotetext{
${ }^{27}$ David Crossland, "Fighting the Far Right: One German State's Losing Battle Against Extremism," Der Spiegel, September 6, 2011.

${ }^{28}$ de Pommereau, "German Children," 6.

${ }^{29}$ Patricia Hogwood. "'How Happy are You ...?' Subjective Well-Being in East Germany Twenty Years after Unification," Politics 31, no. 3 (October 2011): 151.
} 
and a nation of suffering victors in the West. It is the culmination of a trend of Wall memorials in Berlin that began after 1999. Before then, however, a different style of commemoration had earned the spotlight.

Prior to 1999, in searching for monuments and commemorative spectacles specifically related to 1989 , what one finds is a lack of concrete examples rather than the plurality that one might expect. Instead of following in the tradition of older revolutions in either country, commemorations surrounding 1989 tended to be more academic in nature, and certainly seemed to encourage the commemorator to be inwardly reflective rather than outwardly ebullient. This new pattern was a thoughtful shift towards a more moderated world, away from the monument heavy ethos of nationalist $19^{\text {th }}$ and $20^{\text {th }}$ Century Central Europe. Such reasoning is in line with the peaceful negotiated revolution in Germany, and the FRG's post-war policy of moderation at all costs, a policy which helped contribute to the stability of the West German government in turbulent times, from Konrad Adenauer to Helmut Kohl. ${ }^{30}$

One of the distinguishing features of Wall remembrance in the decade immediately following 1989 was the decentralized nature of commemorative efforts. Even the few official public commemorative sites that existed were still purposefully decentralized, and often placed in parts of the city that had little tourist traffic. The

\footnotetext{
${ }^{30}$ Timothy Garton Ash, History of the Present: Essays, Sketches, and Dispatches from Europe in the 1990s, (New York: Random House. 1999): 258. According to Timothy Garton Ash, "It is a remarkable fact that, in the whole previous history of the Federal Republic, the government has never completely changed as a direct result of the popular vote. Either the governing coalition has changed between elections or, in the rare event of it changing at an election, one previous coalition partner has remained in power." This fact held true until the election of Gerhard Schroeder, who replaced Helmut Kohl as German chancellor.
} 
governing ethos of the era was one of anti-monumentalism, a strong break with Berlin's Prussian, Wilhelmine, and National Socialist past. This break should by no means be shocking. After all, both the FRG and GDR had spent the five decades since the end of the war distancing themselves as much as possible from the monumentalist cultures that had dominated political life in the country in its past, and led it into economic and physical ruin.

Since 1999, however, the attitude towards commemorating the Wall has changed in Berlin. The Berlin Senate, under pressure to produce a tourist-ready, centralized commemorative site, has bowed to demands and progressively centralized Wall memorials around a facility on Bernauer Straße. Private attempts since 1999 have also been successful at co-opting attention and tourist dollars, most notably Ukrainian-born Alexandra Hildebrandt and her Haus am Checkpoint Charlie and Freiheitsmahnmal in 2005-2006. These later efforts arose for two reasons. In part, they stemmed from a view of the GDR generated by research done under the auspices of the Gauck Authority, the monolithic institution designated to archive all former Stasi files. The second reason these later memorials came into existence was as a direct result of Right-wing reactions to a failure by the Left to properly, in their opinion, memorialize the struggle of East Germans under Communism. The political Left had held a more prominent role in the federal government under the chancellorship of SPD politician Gerhard Schroder after the failure of Helmut Kohl and the Christian Democrats to maintain power for conservatives in the 1990s. This mirrors a similar situation that also affected Polish commemorations, as shall be seen later. 
Debates over how the wall should be remembered began almost as soon as it fell. While factions were arguing the merits of leaving up portions of the wall for memorial purposes or if it should be torn down in its entirety, the government, souvenir seekers, and enterprising entrepreneurs settled the matter for them. The wall, which began to be referred to in the past tense even before it was completely demolished, was taken apart piece by piece and reutilized for building projects within the city, though some individuals capitalizing on worldwide demands collected pieces of the wall and shipped them to buyers all over the globe. Over the next few years there was no major public attempt to organize a central facility to remember the wall, although over 100 different memorials now exist in the city.

Before 1999, the biggest single memorial to be planned for Berlin would be the controversial Memorial to the Murdered Jews of Europe, alternately referred to as the Berlin Holocaust Memorial. ${ }^{31}$ This particular monument, massive in scale, provoked a protracted debate over its appropriateness, particularly in its form and location. ${ }^{32}$ The monument was to be (and since has been) erected near to the Brandenburg Gate, purposefully situated on a site where the Wall used to run, forcing Berliners to draw comparisons between the two events upon any reflection of the monument. This naturally provoked ire in some, who felt that the events should be remembered separately, if remembered at all. To many Germans, the Wall has come to represent German victimization and suffering, an unfortunate if albeit more comfortable past emotionally,

\footnotetext{
${ }^{31}$ Karen E. Till, The New Berlin: Memory, Politics, Place (Minneapolis: University of Minnesota Press, 2005), 161-188.

${ }^{32}$ The Memorial actually takes up a large city block between two bustling centers, the Pariser Platz and the Potsdamer Platz.
} 
whereas the particular placement of a prodigious monument to Nazi atrocity is a thorn in the paw of the German collective consciousness.

Another concern over the monument, even amongst those who felt that the discussion of Germany's principal role in the Holocaust was open for public discussion, was the fear that such a massive memorial would change the landscape of Berlin. They wanted Berlin to be a living, new city, and in the 1990s the term "New Berlin" took root as building projects skyrocketed and money was poured into neglected areas of the city. Berliners did not want to be hampered by the ghosts of the past, a feeling which prompted one graffiti artist to tag "Die Diskussion ist ein Mahnmal," on the side of the uncompleted project. $^{33}$

The drama surrounding the Berlin Holocaust Memorial is a prime example of Berlin's struggle to deal with historical overlap. In a place where memory seems destined to be determined by space, the issue of how to utilize those spaces has become increasingly difficult. As seen by the declaration, "The discussion is a monument," many Germans would rather relegate their historical memory to temporal space rather than physical space. Perhaps the motivation behind this is the desire to heal old wounds and rebuild, rather than allow the memory to linger indefinitely. Yet it is apparent that there is also a desire to allow for an open and very physical discussion of the past, reflected by the monuments themselves. By constructing monuments on top of one another, or more specifically to build a Holocaust memorial near to an important Cold War artifact, Germans are drawing a direct connection between the two events. That the ultimate decision was in favor of the monuments speaks to the fact that Germany has decided its

33 "The discussion is a monument." Till, New Berlin, 3. 
history must be remembered physically, and that rebuilding efforts would have to coexist with the desire to physically remember.

As for other commemorative efforts in Berlin directly involving the end of Communism, the trend in the 1990s was for reflective, impermanent monuments. The biggest effort to commemorate the Wall was the public Übergänge competition from 1996-1999, which allowed entrants to submit proposals for public art installations across the city. ${ }^{34}$ Offering seven different perspectives of the history of the Wall and divided Berlin, Übergänge was a chance for artists to draw on the plurality of the experiences of life in the shadow of the Wall. The projects were also meant to be impermanent, though in many cases there was no specific date to officially end the installations or remove them, meaning that the art pieces themselves would deteriorate and morph over time. This was in fact an intentional aspect of Übergänge developed by the competition designers and was meant to instill the sense that interpretations of the Wall and the GDR would inevitably change over time, so the monuments should change with them. ${ }^{35}$ There is no such thing as a permanent monument, at least in terms of meaning. A large stone monument may last for a thousand years, but its intended meaning, whether created by a private individual or group or funded publicly by a government at any level, will inevitably change as popular memory shifts. Examples of this are numerous, and many of the most prominent are in areas that have seen the rise and fall of the nationalism-charged period of the $19^{\text {th }}$ Century, fascism, and communism. Included in this list are the Hungarian Millennium Monument and Berlin's Brandenburg Gate.

\footnotetext{
${ }^{34}$ Anna Saunders, "Remembering Cold War Divisions: Wall Remnants and Border Monuments in Berlin," Journal of Contemporary European Studies, Vol. 17 No. 1, 9-19 April, 2009, 13.

${ }^{35}$ Ibid, 14.
} 
Though decidedly not a German monument, the story of the Millennium Monument is still one of the most fascinating examples of what one monument can come to represent over time, and how the changing winds of national memory can still embrace it even when the national direction is so far from the monument's roots.

Originally constructed to commemorate one-thousand years of the Habsburg dynasty, even as that glorious bastion of imperialism was beginning to waver under the strains of growing demands from competing nationalities, Budapest's Millennium Monument was to enshrine the Hungarian people's love of their Habsburg emperor Franz Josef. But with the dissolution of the Habsburg Empire at the end of the First World War, the Millennium Monument became a relic of a bygone era. Almost overnight, its meaning was changed forever.

But the story of the Millennium Monument does not end there, because even after communism took hold of Hungary, the monument to Hungary's long deceased foreign emperors remained. Hungarian Communists were unwilling to remove the statue, which stood for everything they opposed, because "[they] were unwilling to pay the potential political costs of destroying what had become a central public symbol of the Hungarian nation."36

The Millennium Monument thus serves as a perfect example of the value of physical landmarks in culture, but also of the often-unstable nature of their representative status. Monuments easily become "central public symbols," but can be repurposed by

\footnotetext{
${ }^{36}$ Sanford Levinson, Written in Stone (Durham: Duke University Press, 1998), 9.
} 
later generations with differing affiliations for the "ideological purposes of forging a new...consciousness. ${ }^{, 37}$

The Brandenburg Gate is another powerful symbol of the strange effects of landmarks through time, and of Germany's continued struggle with overlap. Next to the wall, the Brandenburg Gate is easily one of the most recognizable symbols in Berlin, yet its recognizability spans multiple epochs, leaving the towering monument imbued with a plethora of possible emotional responses. Sanford Levinson has said, "All monuments are efforts, in their own way, to stop time. ${ }^{38}$ In a way they do accomplish this, but the unintended consequence of monuments is that so often the collective vision of the time that the monument is meant to represent changes. Furthermore, it is entirely possible for a monument to come to represent a multitude of moments in time. A visitor remarking the grandeur of the Brandenburg Gate can at once envision the imperial dreams of the militaristic Prussians, with the goddess Nike perched atop, waving them on to victory. Simultaneously, the Brandenburg Gate can be a backdrop for a torchlight parade of Nazis; as an abandoned ruin in the heart of divided Berlin; or, conversely, as a symbol of unity with thousands of champagne popping, cheering onlookers watching as the Berlin Wall is rendered irrelevant.

Perhaps unsurprisingly, since 1989 the area around the Brandenburg Gate has become Berlin's unofficial "Memory District." Stretching out south from the Reichstag, lies a series of memorials that incorporate different layers of Berlin's history, including the Memorial to the Murdered Jews of Europe, Unter den Linden, the Brandenburg Gate and Pariser Platz, Checkpoint Charlie and Haus am Checkpoint Charlie, the Topography

\footnotetext{
${ }^{37}$ Ibid, 9.

${ }^{38}$ Ibid, 7.
} 
of Terror, and the Jewish Museum. ${ }^{39}$ A common theme of these exhibits is one of overlap. The northern boundary of the Topography of Terror, an installation intended to instruct the visitor of the disturbing realities of the Gestapo, is an intact portion of the Berlin Wall. ${ }^{40}$ Without needing to be explicitly stated, there is a natural comparison being drawn between the two events from different eras of German history. The wall, a symbol of repression, subjugation, and division, was a direct result of the policies that created the Gestapo. The overlapping monuments serve as a reminder to Berliners and tourists of the negative consequences and grim realities of radical politics.

Beyond Berlin's permanent monuments that seek to blend collective memory, two artificial post-1989 installations in particular, different in both meaning and function, gained the most notoriety among visitors and the public. The Übergänge art competition of 1996-1999, publicly backed by the Berlin Senate, was a chance for artists to offer their own vision of the wall. ${ }^{41}$ The artists were allowed a great deal of scope, and did not have limitations on the message they chose to send. Some of the messages were reflective, some were humorous, some were hopeful, but all of them offered a unique interpretation of what the wall could mean to Germans on either side. They reflected the plurality of opinions, and did not relegate anyone, East German or West German, into the category of victim or perpetrator. Übergänge was instead a humanistic interpretation of 1989, and as such was a chance for Germans and foreign tourists to move beyond the radical past.

\footnotetext{
39 Till, New Berlin, 198.

${ }^{40}$ Irwin-Zarecka, "Topography of Terror." See also: Saunders, Border Monuments, 4-5. Saunders also muses that the conjunction of two points in time "confuses less historically aware tourists - some of whom believe the Wall to date from National Socialist times." ${ }^{41}$ The English translation of Übergänge is "Crossings." Each installation, seven in total, was to be placed at one of the seven former border crossings of the Berlin Wall. http:/www.berlin.de/mauer/grenzuebergaenge
} 
The seven artists whose designs were chosen were: Frank Thiel, Gabriele Basch, Heike Ponwitz, Karl Sachse, Susanne Ahner, Thorsten Goldberg, and Twin Gabriel. ${ }^{42}$ Of these artists, several stand out as being the most memorable and most popular. Thorsten Goldberg's "Stein-Papier-Schere" at the Oberbaumbrücke Bridge is quite a unique sight. Suspended in the supports of the elevated rail bridge, Goldberg has placed two round neon lights, which turn on in the evening, each alternating one of three possible signals: rock, paper, scissors. The ongoing competition between the two hands is meant to "raise the question of how decisions are made." Much in the way that political decisions are often greeted by confusion, the competition committee was particularly swayed by the way the art "subtly [integrated] itself into the structure - the way coats of arms would be lined up - and yet [provoked] viewers' confusion.",43

Karla Sachse's Kaninchenfeld at the Chauseestraße crossing is a playful look at some of the most successful Wall subversives: the famous rabbits who managed to make their home in the no-man's-land of the infamous Death Strip. ${ }^{44}$ The silhouettes of 120 rabbits, an "object of projection for people on both sides of the Wall," are meant to assert their "independence from the unreasonable demands of political didacticism," according to the jury. ${ }^{45}$ The rabbits dot the street and sidewalk around the former border crossing, although in keeping with the theme of the contest, over time the rabbits have been

\footnotetext{
${ }^{42}$ Twin Gabriel is a collaborative name for two artists: Else Gabriel and Ullf Wrede. 43 "Stein-Papier-Schere," Thorsten Goldberg, 1997. http:/www.berlin.de/mauer/grenzuebergaenge/oberbaumbruecke/index.en.php?objekt=2 ${ }^{44}$ Saunders, Border Monuments, 6-7. Kaninchenfeld translates to "Rabbit Field." http:/www.berlin.de/mauer/grenzuebergaenge/chausseestrasse/index.en.php?objekt=2 45 "Kaninchenfeld" (Rabbit Field), Karla Sachse, 1999. http:/www.berlin.de/mauer/grenzuebergaenge/chausseestrasse/index.en.php?objekt=2
} 
incorporated into the city, as buildings and other permanent structures pave over Sachse's vision.

Perhaps the simplest of the art installations to understand, at least from a visitor's perspective, are Frank Thiel's Ohne Titel light boxes located at the former site of Checkpoint Charlie on the Friedrichstraße, the famous border between the American and Soviet sectors of Berlin. ${ }^{46}$ These light boxes are identical to others found all across Berlin that are used for advertising purposes, only here instead of corporate slogans, the light boxes contain pictures of soldiers, one American, one "Soviet," facing off in an eternal staring match. ${ }^{47}$ The overt symbolism of the two portraits is not hard to lose. According to Thiel, "these portraits translate the omnipresent sector signs of the past - 'You are leaving the American/British/French sector' - into picture form...By using two portraits to symbolize almost 50 years of history, I am suggesting that these two faces are representative. ${ }^{, 48}$

Thiel's vision, putting a human face to the division of Berlin, was representative of the Übergänge project as a whole. It was meant to be a reflective project for people to remember the recent past and the experiences they and their countrymen went through. There was no blame assigned to any person or group, and was instead intended to foster new community growth processes. A major factor of Übergänge, one that separates it

\footnotetext{
46 “Ohne Titel” (light boxes), Frank Thiel, 1998. http:/www.berlin.de/mauer/grenzuebergaenge/friedrichstrasse/index.en.php?objekt=3 ${ }^{47}$ Ibid. "The photos were taken in 1994 before the Allied forces withdrew from Berlin. Since the Soviet Union disintegrated in 1991, the 'Soviet' soldier is wearing the uniform of the new Russian federation."

${ }^{48}$ Ibid.
} 
from later publicized memorials, was that it was far less concerned with tourist traffic. ${ }^{49}$ Übergänge was attempting to encourage thoughtful growth without relying on any one group's post-Cold War ideology.

Occurring simultaneously with the Übergänge competition was the development of a new archive, known as the Gauck Authority, which sought to bring to light the Byzantine structure of the hated Stasi security force. Though intended as an open resource for researchers, legal structures and inherent defects of the authority's administration would have a longer lasting impact on German memory formation than Übergange, and would help usher in a new mode of thinking about East Germany that would directly influence memorials in the future.

As the discussion of Übergänge has shown, the decade after 1989 in Berlin was an odd memorial landscape. Some effort was made to commemorate previous historical events, as evidenced by the Berlin Holocaust Memorial and the Topography of Terror, but little was done to commemorate the end of communism. It has been suggested that this is because Berliners were unsure how to broach the subject. The art installations of Übergänge are reflections of uncertainty. Coming to terms with reunification, Boym postulates, has been a major hurdle to commemorations. She recognizes that, "Before 1989, there were two German states - German Democratic Republic (GDR) and Federal Republic of Germany (FRG) - but presumably one cultural tradition and one nation. Now it turns out that there is one state with two different nations, Ossis and Wessis, with their

\footnotetext{
${ }^{49}$ Heike Ponwitz's “Übergäng - Nähe und Distanz” (Crossing: Proximity and Distance) is the most reflective of this. Located at the former Sonnenallee crossing, this installation exists off the tourist trail "at the edge of an unspectacular housing development." http:/www.berlin.de/mauer/grenzuebergaenge/sonnenallee/index.en.php?objekt=3
} 
own cultural traditions and frameworks of collective memory." ${ }^{50}$ While Übergänge directly addressed this issue, other institutions like the Gauck Authority and later the Haus am Checkpoint Charlie sought to challenge and even revise this charge by forging a new identity for Germany.

Economy was also a factor in the inability to commemorate 1989. Berlin was a city focused on rebuilding itself after decades of division. Instead of focusing on painful events of the past, it was more interested in building for the future, indeed, "The key word of New Berlin is normalization, not memorialization." ${ }^{\text {51 }}$ This static, anti-memorial status could not last in Berlin, however, because in any society, questions about the present-day's relationship with the national past will arise. The past must always inform the present, even if that past is glossed over and reinvented to fit the ethos of the day. "What neurosis is to the individual," Schivelbusch reminds us, "the creation of myths is to the collective." 52

The famed Gauck Authority was a central organization created to determine how Germany would remember its Communist past, and would later serve as the model for the Polish Institute of National Remembrance ${ }^{53}$ As an institute dedicated to memory, the Gauck Authority acted as a bridge between the memory void of immediate post-1989

${ }^{50}$ Svetlana Boym, The Future of Nostalgia, (New York: Basic Books, 2001). 177.

${ }^{51}$ Ibid, 176.

52 Wolfgang Schivelbusch, The Culture of Defeat: On National Trauma, Mourning, and Recovery, New York: Picador, 2004. 26.

${ }^{53}$ The Gauck Authority is the popular but unofficial name for the Federal Commissioner for the Stasi Archives. The authority always takes its name from its current director. The Gauck Authority lasted from 1990-2000, followed by the Birthler Authority from 20002011, and currently the Jahn Authority. Joachim Gauck is the current president of Germany, having been appointed by Chancellor Angela Merkel on February 19, 2012. Sarah Marsh, "Former Rights Activist Gauck to Become German President." Reuters. February 19, 2012. http://www.reuters.com/article/2012/02/19/us-germany-presidentnewsmaker-idUSTRE81I0RA20120219. 
years and the period of reverential remembering that would follow. Perhaps most notable for its archival division, which allows researchers to view former Stasi (East German secret police) files, the Gauck Authority also served a political function. The first commission, established by the Bundestag in 1992, was tasked with inquiring into the "history and consequences of Socialist dictatorship in Germany." ${ }^{\text {"54 A Second }}$ Commission was established in 1995 with a similar purpose, and its findings directly impacted, or perhaps reflected, the nation's views on memorialization.

The second commission advocated for a Federal Memorial Program to be placed in charge of funding and constructing "monuments recalling the horrors of both German dictatorships. ${ }^{, 55}$ While this program never came to full fruition, the Gauck Authority continued to have a major impact on the development of German national memory, particularly for its methods in approaching the study of the Stasi archives.

Several laws passed in the early 1990s were meant to help facilitate research into the Stasi files. In 1991, the Bundestag passed the Statute on Stasi Files, which defined rules on access to the Stasi files, such as an odd anonymization process that placed the "selection of research materials into the hands of untrained lay people." ${ }^{" 56}$ Through this system, a researcher would place a request for files, which would then be retrieved and compiled by an authority archivist and brought back to the researcher. Two problems lie in the way. First, Stasi files were not compiled alphabetically by the name of their subject, which would have made retrieval and review significantly easier; rather, they

\footnotetext{
${ }^{54}$ Inga Markovits, "Selective Memory: How the Law Affects What We Remember and Forget about the Past-The Case of East Germany," Law \& Society Review. 35, no.3 (September 2001), 517.

${ }_{55}^{55}$ Ibid, 517.

${ }^{56}$ Ibid, 541.
} 
were compiled by date of birth, which required archivists to utilize personal judgment as to which files were appropriate to include.

This led to the second problem, which is the type of information that was brought to researchers. Because discretion was given to archivists as to what information to provide researchers, frequently only the most scandalous information was being brought out. Poorly trained archivists were left to interpret what was important, and in doing so often gravitated toward the sensational rather than the seemingly mundane, when in fact those everyday commonalities of life in the GDR were precisely what researchers were looking for. In practice, this statute "facilitates investigations of the scandalous and hinders research into the 'normal' impact of Stasi activities (if we can ever [call] the Stasi 'normal')."57 The selective process leading to only the dissemination of mainly sensationalist material has contributed to the view of the GDR as an "Unrechts staat.",58

The 1992 Law Amending the Federal Law on Archives had a similar impact on the control of information coming from the Gauck Authority. This law exempted the "Archive of the Parties and Mass Organizations of the GDR" from a thirty-year grace period that still protected comparable documents from West Germany. The result is an abundance of free information from the former GDR, but practically nothing from West Germany. The result of this dilemma is that "the history of Socialism in East Germany already filled with shocking events - appears all the more shocking when set against the discreet background of West Germany's past." ${ }^{, 59}$ Intentionally or otherwise, legal structures regarding the dissemination of information from archives of both East and

\footnotetext{
${ }^{57}$ Ibid, 541.

58 "State of unlawfulness or injustice." Ibid, 542.

${ }^{59}$ Ibid, 541.
} 
West Germany in the immediate aftermath of reunification created a system that was inherently inclined to protect the memory of West Germany. The sins of East Germany, but not its normalcy, were made far more apparent, and far more accessible to researchers. For all of the real good that it has done, the transparency of the Gauck Authority is less than it may appear to be. The Gauck Authority provides a great open resource to research the Stasi, but it is not neutral in its impact on memory formation, in that it serves to enforce the memories of the Western winners. This officially sponsored view of the East German security apparatus and how it impacted life in the GDR had a direct influence on the sorts of imagery and ideology that would become more apparent and accessible in Berlin starting in the $21^{\text {st }}$ Century, and would be reflected most clearly by the Freiheitsmahnmal and Haus am Checkpoint Charlie.

In respect to previous attempts to memorialize the end of Communism, particularly compared with the Übergange competition, Alexandra Hildebrandt's Freiheitsmahnmal was something completely different. Instead of drawing on the plurality of experiences of life in divided Berlin, Hildebrandt's field of 1065 wooden crosses, each denoting a victim of wall violence, sitting in front of a reconstructed section of the Berlin Wall, fit squarely into the Western conception of East Berliners as being either victims of perpetrators, a belief mirrored within the structures of the Gauck Authority. ${ }^{60}$ The Freiheitsmahnmal gave tourists something that they had been wanting but desperately lacked: a centralized spot that fit their view of the wall, from which to remember wall victims. They responded in droves. In the brief time that it existed, it

\footnotetext{
${ }^{60}$ Saunders, Border Monuments, 7.
} 
became the favorite central spot for tourists. It did not hurt that Haus am Checkpoint Charlie, the museum of which Hildebrandt is the director, was located next door.

Freiheitsmahnmal was a site of "highly ritualized memory," with a wreath laid for every victim and "every cross...blessed by a Catholic priest." ${ }^{\circledR 61}$ Importantly, Freiheitsmahnmal was Hildebrandt's attempt to strike out at the fact that there was no formal centralized place from which to remember the wall. Up to that point, Übergänge had been the only attempt at memorialization by the Berlin Senate. At the same time, other victimized groups, particularly Jews, were finally breaking ground on having centralized, official locations of their own, including the new Jewish Museum and the Memorial to the Murdered Jews of Europe. So Freiheitsmahnmal was an attempt to give wall victims their due.

Also unlike Übergänge, Freiheitsmahnmal was a privately funded memorial. Rather than the result of a competition, with a panel of jurors in an attempt at acknowledging all points of view, Freiheitsmahnmal was backed by corporate and political organizations with a very specific point to press. It also gained notoriety because it was only a temporary exhibition, as the land on which Hildebrandt constructed the memorial was leased from a bank. Hildebrandt and her supporters, a collection of victims' families, conservative CDU politicians, and German-American advocates (including Daimler-Chrysler), unleashed a media campaign to get the bank conglomeration Bankaktiengesellschaft (BAG) to allow the site to remain in existence. $B A G$, in turn, wished for Hildebrandt to either renew the lease or purchase the site. Coincidentally, the original date of demolition was scheduled for July 4, 2005, American

${ }^{61}$ Ibid, 8. 
Independence Day. Though the mayor of Berlin generally avoided the conversation surrounding Freiheitsmahnmal, when asked about the demolition date, his spokesperson Michael Donnermeyer responded, "If it is true that the demolition will happen on Fourth of July, this would be mediawise imprudent. One should at least postpone the day.",62

A brochure from Haus am Checkpoint Charlie made no mistake about the target audience of the Freiheitsmahnmal. Included in it is a letter from Michael Inacker, an executive at Daimler-Chrysler, "a German-American company," to Joachen Lehnhoff, Chairman of the Board of Supervisors at $B A G$, proclaiming the merits of Checkpoint Charlie and asking if they could come to an amicable solution. ${ }^{63}$ There is also a document from GOP Germany asking its members to donate to keep the memorial alive. For a donation of US\$250, members could receive a Republicans Abroad “Cufflink/Lapel Pin Set \& Genuine piece of the Berlin Wall., ${ }^{, 44}$

Perhaps as could be expected, there were many critics of Freiheitsmahnmal. In her letter about the importance of keeping the memorial open, Hildebrandt spent most of the time stressing the importance of Checkpoint Charlie, including many of its famous visitors. Some critics claimed that the way in which the memorial was created suggested that many of the victims had died at Checkpoint Charlie, which is of course untrue. In fact, the actual deaths of some of the victims, which Hildebrandt did not limit to just victims killed at the wall, are still in dispute. ${ }^{65}$ What Freiheitsmahnmal accomplished was establishing a centralized location for wall tourism. Even though the memorial itself is

\footnotetext{
${ }^{62}$ Tom Goeller. "Berlin Wall Memorial to be Razed," The Washington Times, June 27, 2005. Hildebrandt, 30 .

${ }^{63}$ Letter from Michael J. Inacker to Joachen Lehnhoff, Hildebrandt, 21.

${ }^{64}$ News article from gopgermany.com, Hildebrandt, 35. The cufflinks and lapel pins feature the Republican Party's traditional elephant logo.

${ }^{65}$ Saunders, Border Monuments, 17.
} 
gone, Haus am Checkpoint Charlie still thrives and serves as an important stop for tourists.

Freiheitsmahnmal also got the Berlin Senate moving, and within the year it created a plan to centralize tourism around the massive $1.4 \mathrm{~km}$ long Berlin Wall Memorial along the Bernauer Straße. ${ }^{66}$ This facility attempts to straddle the line between Freiheitsmahnmal and Übergänge, creating a centralized space for Wall tourism with a clear message, while at the same time trying to allow visitors space for personal reflection to attempt to understand the wall on their own terms.

Since the end of the Freiheitsmahnmal drama, there has been little ceremony surrounding the end of Communism in Germany, with the obvious exception of the twentieth anniversary celebration, which was generally positive. This shift is reflective of political changes in Germany. Politically and economically, Germany has been one of the most stable countries in Europe in recent years. This position has done a good deal to hamper major political divisiveness, which, apart from space and historical overlap, is one of the most major factors to impact identity formation. A more salient example of this is to be found in the recent commemorative history of Poland.

\footnotetext{
${ }^{66}$ Gedenkstätte Berliner Mauer. http://www.berliner-mauer-gedenkstaette.de/en/download/english.pdf
} 


\section{Warsaw Remembers}

\section{A. Background}

Commemorations of 1989 in Poland followed a different arc than in Germany. In part this is due to the nature of Poland's transition from Communism, which was not subject to the complications of reunification; however, perhaps the more important theme that separated Polish and German commemorations were the unintended consequences of the negotiated reforms following the Round Table Negotiations.

Post-1989 Polish commemorations can be defined by two general time periods. The first, which comprised most of the 1990s, was a fallow period for commemoration. There were virtually no state-sponsored attempts to commemorate, the reasons for this being attention to the struggling economy and democracy-building, and a purposeful effort to shy away from remembering Communism under the post-Communist presidency of Aleksander Kwasniewski. Modest attempts were made at the private or local level, usually in the form of new statues or the removal of Communist era statuary.

The second and much more potent era of commemorations began with the creation of the Institute of National Remembrance (Instytut Pamięci Narodowej or IPN) by the Polish parliament in the late 1990s. Initially dedicated as a research organization and archive housing the entirety of former security service archives, the IPN was meant to produce academic work bringing to light atrocities committed during the Nazi and Communist periods of modern Polish history, and if possible bring perpetrators to justice. By 2005, the influence and power the IPN was radically altered by the incoming rightwing Law and Justice party headed by the Kaczynski brothers, former Solidarity activists 
disillusioned by what they perceived as the failures of post-Solidarity and postCommunist leaders to bring "morality" back to Polish politics. Under their leadership, the IPN ballooned to incorporate a powerful new lustration bureau which sought to root out from public service anyone who may have collaborated with the Security Service and expose them to the public. The controversies that followed these efforts will be discussed in detail, as their outcomes have proved highly consequential in Polish politics.

Yet another significant difference between German and Polish commemorations exists, and that is the absence of physical commemorative space. If Germany followed the maxim that space is crucial to identity formation, Poland proves that space alone is not the final arbiter in shaping identity. This is not to claim that Poland does not have its own important spaces. In Gdansk there are the shipyards where the Solidarity strikes began, but that space reflects the beginning of a movement and not the end of communism. Warsaw, too, has its spaces, and as this study will mostly look at commemorations within the Polish capital, where the Round Table Negotiations occurred, a look at identity spaces is also necessary. However, Warsaw has nothing akin to the Berlin Wall. There are structures in Warsaw that serve as reminders of the Communist past, key among these the Palace of Culture and Science, but again, this structure is indicative of one period of Polish history, and does not incorporate quite the same level of overlap as the Berlin Wall. It was not symbolic of the downfall of communism in Poland, which happened much less gradually than in Germany, and though it sits over an area crucial to the Second World War period, few physical remains of that event can be found anywhere in the city. 
The following discussion will be devoted to the creation of new memory spaces in Poland, particularly within Warsaw. These spaces generally take the form of monuments, which come in different forms. Some are completely new creations, erected after the end of communism to reflect an idealized event or hero from the national past. Others are replacement monuments, taking over spaces previously held by Polish Communist or Soviet monuments. Another form of new identity space is the conspicuous absence of monuments. In these cases, former Polish Communist or Soviet monuments were destroyed, but were not replaced. Often in instances like these, the base of the monument still remains, a testament to the identity of a previous era. This particular brand of commemoration was most prevalent in the period immediately following the end of communism, when there was little in the way of official commemorations.

Later forms of commemoration would revolve around the Institute of National Remembrance, and its use by politicians to directly influence Polish identity. This latter phenomenon, which differs from the way in which the Gauck Authority was used in Germany, is directly linked to the end of communism and the transition period. Critical to this is how differently Poland and East Germany came to restoring a multi-party system. Poland's path to 1989 began earlier than East Germany's. True, the history of both countries, intertwined because of their wartime experiences, means that both nations shared some aspects of the communist era. Yet the actual groundwork for Poland's eventual break with the Communist Party began between 1979 and 1981 . There had been periods of unrest in Poland before then, resulting in the loss of life of Polish citizens, but none of these had been successful in actually making sweeping changes to the government. At most, Poland was left with the freedom to apply its own brand of national 
communism and to have a greater say in its own domestic affairs, something which protestors in Hungary in 1956 looked to when they staged their own failed revolt.

Possibly the most important aspect of these previous crises was the guidance they provided for those who would come later. When the trade union Solidarity formed in Gdansk, its leaders, many of whom had witnessed or even been a part of the strikes of 1970-71, formed new strategies based around the hard lessons they had previously learned. In effect, they were making sure that they took advantage of previous experiences in order to ensure a much greater chance for success.

The election of Cardinal Karol Wojtyla (later Pope John Paul II) to the papacy in 1978, the first Polish pope and first non-Italian pope in several centuries, would become one of the first stepping-stones in Poland's path to reform. ${ }^{67}$ As a deeply devout Catholic nation, there had always been tensions between the Catholics and Communists. One can see how trouble could be created in a society where there was a large base of Catholic workers mixing with the nominally atheist ruling party. Especially furthering the country's aims at greater freedom was John Paul II's first papal visit to his native Poland in 1979. Standing in Warsaw's Victory Square in front of a crowd of thousands, the pope boldly proclaimed:

"We stand here near the Tomb of the Unknown Soldier. In the distant and contemporary annals of Poland, that tomb has had its foundation and justification. In so many different places on their native soil soldiers fell in battle. In ever so many places in Europe and the

\footnotetext{
${ }^{67}$ Gale Stokes. The Walls Came Tumbling Down: The Collapse of Communism in Eastern Europe. New York: Oxford University Press, 1993. 31.
} 
world their death proclaimed that there can be no just Europe without an independent Poland on its map. ${ }^{, 68}$

The pope's words did not fall on deaf ears. The Polish people heard in the Pope's remarks as further legitimization of their cause, which inspired reformers to carry on the work that had been left aside in 1970 and picked up by KOR, after Gierek's policies of raising workers' wages, which he later returned to normal, had appeased protestors for a brief time. $^{69}$

By 1980, workers in the Lenin Shipyard in Gdansk were ready to push for one of the main demands of 1970, which had been for the establishment of an independent trade union. Strikes began in June 1980 across the country, but most were fairly short-lived. The strikes would not touch the Lenin Shipyard until August, since strike organizers could not persuade the other workers. All of that changed, however, when a crane operator named Anna Walentynowicz was laid off.

Walentynowicz had been a popular worker who was outspoken against corruption, and her unfair sacking gave organizers the impetus they needed to persuade their fellow workers to strike. ${ }^{70}$ Among their demands were that both Walentynowicz and another popular worker, an electrician named Lech Walesa who had been laid off in 1976, be allowed to return to work. The strike nearly collapsed when the manager of the yard promised that he would be willing to negotiate with the workers if they would return to work, but it was just at that moment when Lech Walesa jumped up next to him and

\footnotetext{
${ }^{68}$ It All Began in Poland...1939-1989. Ministerstwo Kultury i Dziedzictwa Narodowego: Warsaw, 2009. 125.

${ }^{69}$ Stokes, Walls. 18.

${ }^{70}$ Ibid., 35.
} 
spoke to the crowd. ${ }^{71}$ The strikes continued, with Walesa taking the leading role, and soon workers from across Poland had resumed their strikes. On August 17, 1980 the Międzyzakladowy Komitet Strajkowy, led by Walesa, released a list of twenty-one demands, the first of which was the establishment of an independent trade union. ${ }^{72}$ The demands eventually led to the Gdańsk Agreement and the formation of the independent trade union Solidarity.

From those beginnings Solidarity would grow into a massive force. It was recognized internationally, and became a symbol in the western world, which viewed Solidarity as the people of the Communist bloc finally taking a stand against their leaders. From the Pope's Warsaw visit to the emergence and actions of Solidarity, there were growing signs that Poles were simply fed up with the Communist government and were finally going to act against it. The provocations of Solidarity were serious enough for Polish Prime Minister General Wojciech Jaruzelski to declare a state of martial law in December 1981, violently cracking down on Solidarity and the opposition protestors. For nearly a decade, until 1989, Poland would see a period of repression followed by attempts to reform, but it would also experience growing and new forms of opposition. This resulted in a curious situation in which both Solidarity and the ruling party were in a weak position, forcing the party to invite Solidarity to the negotiating table in order to strike a deal regarding a round of multi-party elections. From there, Solidarity went on to an almost clean sweep of the seats for which it posted a candidate, establishing June 4, 1989 as the day that saw the first non-communist government in Eastern Europe since

\footnotetext{
${ }^{71}$ Ibid., 35.

${ }^{72}$ Ibid., 36-37.
} 
World War II. Coincidentally, the positive news of the Polish elections was marred by one thing that day: the Tiananmen Square massacre.

In Polish commemorations of 1989, there is one keyword that reappears more than any other: Solidarity. The famous red logo has become more than a symbol of anticommunist opposition, but also of Poland itself. When celebrating the collapse of communism in their country, Poles tend to identify so strongly with Solidarity that it becomes easy to think that Solidarity alone managed the force the communists into negotiations. This is not the case. Any reasonable person cannot deny Solidarity's importance. It was the strongest and best organized movement against communism in all of Central and Eastern Europe. Its influence expanded so much that sister organizations developed throughout the communist countries of Europe, and some even grew in Western Europe as well. ${ }^{73}$ And, of course, there is the fact that during the Round Table negotiations, the opposition was represented by Solidarity, and the first non-communist elected officials in Poland had a Solidarity background. To give Solidarity the spotlight in any celebration of the end of Polish communism seems obvious enough; however, perhaps that spotlight is sometimes too strong.

After martial law was declared, Solidarity was forced underground. Its leaders were rounded up and imprisoned, or strictly monitored in their homes. With Solidarity made illegal, its leaders were at a real loss to make the same kind of difference as they had in 1980 and 1981. It might have influenced those who were out in the street seeking change, but it did not create new policy on its own. In effect, the efforts that Solidarity had begun were now picked up and carried on by new groups. Along with the

\footnotetext{
${ }^{73}$ It All Began in Poland. 212.
} 
new groups came new causes. Some were in favor of environmental change, others wanted a reform to the compulsory military service system or new alcohol control policies and so on. Many of the new movements were spearheaded by a new generation as well. ${ }^{74}$ They felt that Solidarity, while important as the beginning of people-power movements in Poland, did not belong to their generation, that of young students and workers. These groups took an active part throughout the 1980s in taking their message to the people and championing democratic reforms. Because of their efforts, they managed to get more reformers into the ruling party, and from there the party invited Solidarity to sit down at the Round Table. Within two months, the two sides, both of whom were considered weak at the time, managed to put together a deal in which Solidarity was legalized and which allowed for contested elections in June 1989. The Communists may have thought that they could still work out a way to maintain control of the government, but they were proven wrong. When the election came, Solidarity won almost every contested seat that was on the ballot. ${ }^{75}$

In 1998, on the eve of the tenth anniversary of the Round Table, the University of Michigan hosted one of the most impressive commemorative events in the world, an event that would bring together members from both sides of the Round Table, including many controversial and high profile figures. Their hope was simply to analyze the decision-making process that brought both parties to the table. The commemoration's

\footnotetext{
${ }^{74}$ Padraic Kenney, A Carnival of Revolution: Central Europe 1989, (Princeton: Princeton University Press) 2003. Kenney discusses many alternative movements, the most prominent of which may have been Freedom and Peace and the Orange Alternative. However, these were just two movements during a decade that saw a tremendous rise in "people-power movements," which ranged from political activism, anti-draft movements, religious reformers, ecological reformers, and more.

${ }^{75}$ Timothy Garton Ash. The Magic Lantern. New York: Random House, 1990. 29.
} 
organizers could not have expected the backlash that their event received, a reaction that illustrates the difficulty that memory can play in the comprehension of historical events. In this case, the furor came mostly from the Right, and from Poles still living in Poland as well as those in the United States. The bulk of the criticism revolved around the fact that there was a fear of legitimizing the role of the Communist party by allowing people like Jaruzelski to share equal space with Walesa, never mind the fact that both men played an important role in bringing about the negotiations. ${ }^{76}$ There were also some grumblings from those who believed that the negotiations had "sold out" Poland, in a manner of speaking. These fears rested in a belief that by dealing with the communists, Solidarity had assured its own place by abandoning the positions of others. Basically, the "pinks and the reds," or Solidarity and the Communists, had made a deal that excluded other points of view. These voices wanted it made clear that there were other opposition groups active in Poland, not just Solidarity, but they were excluded from the bargaining table unjustly in their opinion. Also, they felt concern that an unusually large number of former members of the party were allowed to participate in the new government. In effect, the old elites had become the new ones. ${ }^{77}$

For some of the historians involved in the conference, this uproar over what they believed would be a non-controversial conference raised questions as to who exactly was writing the history that they were supposed to be giving a fair assessment of. It is the historian's job to always be unbiased, but in this instance, it was realized that try as he

\footnotetext{
${ }^{76}$ Negotiating Radical Change: Understanding and Extending the Lessons of the Polish Round Table Talks. Center for Russian and East European Studies: Ann Arbor, MI, 2000. 53-54.

77 Ibid., 54.
} 
might, a historian creates history just by defining what is important and what is not. ${ }^{78}$

Despite the historians' best efforts, their attempts at an unbiased approach to 1989 would ultimately prove futile, because by making the choice, consciously or unconsciously, to exclude specific elements of the Polish revolution from their commemoration, they were placing one point of view, one narrative, firmly above another. This is not an uncommon aspect of understanding history as a collection of narratives; in fact, it is the day-to-day reality of it. But whereas the historian may recognize his predicament and attempt to find a remedy, such recognition is less forthcoming in the realm of public commemoration, where a created narrative in the service of collective memory is frequently the point.

The Michigan incident is a perfect example of Michel Rolph Troulliot's "silences" in history. The post-modernist ideal surrounding this theory is that, as the Michigan historians alluded to, history is created as much by the absent spaces in time as by those we remember. ${ }^{79}$ Collective memory is highly selective, and only those things which are applicable to current ways of thinking will be remembered by the group, even if it is the case that an individual's memory recalls something different. In Michigan, two opposing memories squared off against one another. It would be improper to call either illegitimate, since to those who believe in them, the memories are true. But both conspicuously rely only on the individual memories applicable to the collective memory of the adherent.

\footnotetext{
78 Ibid., 52.

${ }^{79}$ Michel-Rolph Trouillot, Silencing the Past: Power and the Production of History. (Boston: Beacon Press. 1995), 26-30.
} 


\section{B. Commemorations}

Discussing the commemorations of 1989 in Poland is an altogether different task than in the case of Germany. Poland, for instance, does not have the benefit of a single, physical object to commemorate, like the Berlin Wall. It had the Round Table, but as a symbol that does not have the same dramatic impact that the wall had in Berlin, where it was a permanent institution for nearly three decades. Instead of one, dramatic event, Poland had a decade-long organized push to revolution, beginning with $K O R$ and the Solidarity movement.

In addition to the absence of a space on which to pin its commemorations, Poland suffered an immediate crisis in leadership after its transition to a democratic government. This impacted the foundations of the government so much that it split apart the Solidarity movement, the result of which was to question the legitimacy of some of its top public figures. With the former opposition split into factions, there was less chance of consensus among leadership at the top, leading to a decreased likelihood of centralized memorials pertaining to 1989 .

A major contributing factor to commemorative life in Warsaw is the Instytut Pamięci Narodowe (IPN), established by the anti-Communist Solidarity Electoral Action government in $1998 .^{80}$ Originally intended to prevent "wild lustration," the Institute was first charged with the task of organizing and maintaining the former Communist security

\footnotetext{
${ }^{80}$ Can be translated as "Institute of National Remembrance." James Mark, Unfinished Revolution: Making Sense of the Communist Past in Central-Eastern Europe (New Haven: Yale University Press, 2010), 48. Practically, the organization began to function in 2000 .
} 
service's files. ${ }^{81}$ Over time, though, it has become something else. After the creation of a Lustration Bureau in 2005-2006 by the right wing anti-Communist Law and Justice Party, the Institute played a central role in providing material to the vetting of candidates "standing for public office or belonging to key professions." 82

The Instytut Pamięci Narodowej plays another important role in Polish commemorative life. Because of its status as an official keeper of modern Polish memory, it is charged with the task of shaping how Poland should remember its past. For the most part, IPN deals with the Polish experience under Nazi occupation and crimes under Communism. However, because of its role in dealing with life under Communism, it must also deal with 1989.

Commemorating 1989 in Poland is difficult for two reasons. The first is that Poland does not have its wall moment in the same way Germany does. There was no one pervasive symbol in Polish society whose destruction would merit a series of memorials, except of course for communism itself. The second reason is the fact that Poles are still divided on the issue of the break with communism. While a majority may have accepted the Round Table negotiations and the elections of 1989 as a success and a full departure from the past, others, especially those on the Right who did not participate in the negotiations, have been more inclined to decry the negotiations as not enough.

After 1989, the successful anti-Communists who assumed power believed that the "Round Table negotiations of 1989 had embodied a sufficient denial of totalitarianism." 83 At first, or at least until 2005 before the Law and Justice government, acts to purge

\footnotetext{
${ }^{81}$ Ibid, 48.

${ }^{82}$ Ibid, 49.

${ }^{83}$ Ibid, 29.
} 
Communists through a formal policy of decomunizacja were discouraged. In fact, Communists were allowed to rejoin the political system, under a new name, and participate in public life. Amongst the most prominent of these former communists was Aleksander Kwaśniewski, elected President in $1995 .{ }^{84}$

But all was not well in Poland, because for many on the Right, memory was not satisfied. Poland had just come through a long period of national suffering, and there were people who felt that the only true revolution was not a negotiated one, but one in which the people triumphed dramatically over the oppressor. In other words, antiCommunist groups that did not participate in the Round Table negotiations "did not accept the logic of compromise, did not believe that the negotiated settlements could provide an appropriate anti-Communist mythology for a new national memory. ${ }^{, 85}$

For the IPN, the agency tasked with remembering crimes of the Nazi and Soviet regimes, there needed to be more substance to successfully satiate all parties involved. Therefore, after the tenth anniversary of the Round Table, the IPN launched a memorial campaign that "avoided the story of elite-level reconciliations that underpinned the transition in 1989, and instead sought to provide a historic story of earlier popular resistance to Communism." ${ }^{.86}$

The IPN followed suit with a similar campaign in 2009 titled It All Began in Poland. By saying "It all began," the IPN was not merely referring to 1989 and the Round Table and June $4^{\text {th }}$ elections, but rather the whole crux of $20^{\text {th }}$ Century history. It draws a direct line from 1939-1989, fifty years of history, through Poland. What began in

${ }^{84}$ Colin Graham, "Poland's Memory Crisis," History Today; 58, no.11 (2008).

${ }^{85}$ Mark, Unfinished Revolution, 30.

${ }^{86}$ Ibid, 52 
the Second World War, when Germany invaded Poland, ended in 1989, when Poland's successful opposition won a groundbreaking election in Poland's parliamentary election, setting the stage for other countries to follow suit.

Through its efforts to bring multiple decades of Polish history into one story, the IPN used historical overlap much in the same way that Germans drew a direct line from the Topography of Terror and the Berlin Holocaust Memorial to the Berlin Wall. By drawing on a fifty-year period instead of 1989 alone, the IPN allowed Poles enough space to remember as they see fit. It also allowed them to draw on a favorite figure of Polish memory, the Polish national hero, specifically wartime heroes. For this, there is a long tradition.

Commemorations have been imbedded in the national consciousness of Poland since the failure of the uprisings of the $19^{\text {th }}$ century made them the greatest showcase for Polish nationalism. The downfall of the Polish state and the tripartite partition of Poland between Imperial Russia, the Habsburg Empire, and Prussia left Poland in the tenuous position of being a stateless nation. In order to cope with this situation and retain a heritage and culture that was divided among three very different administrative bodies, commemorative efforts of the late 19th and early 20th centuries became a means of peacefully uniting Poles. ${ }^{87}$

Without a state to call their own, Poles in the late $19^{\text {th }}$ Century were often left with little or no formal education in Polish history ${ }^{88}$ Commemorations were necessary in

${ }^{87}$ Patrice M. Dabrowski, Commemorations and the Shaping of Modern Poland (Bloomington: Indiana University Press, 2004), 1-133.

${ }^{88}$ Ibid, 6-7. 
order to determine who was Polish, and what it meant to be Polish. In effect, commemorations defined the nation.

This trend was carried on into the $20^{\text {th }}$ Century, and is still in practice. For example, one of the most unusual but informative scenes that occurred in 1989 was a performance piece put on by none other than Lech Walesa. After the Round Table Negotiations paved the way for semi-free elections on June $4^{\text {th }}$, Solidarity set into motion a massive voter turnout drive to ensure that it won as many of the seats that it was up for as possible. The “High Noon" campaign poster was a famous part of this effort, as was Walesa's photo campaign in which he had his picture taken with every Solidarity candidate. Juxtaposed to this relatively conservative election campaign was Walesa's May $14^{\text {th }}$ spectacle in Racławice. The spectacle on that day "showed sweeping disregard for conventional constraints. ${ }^{~} 89$

Walesa's performance focused on Polish hero Tadeusz Kościuszko’s victory against Russian troops on the battlefield of Racławice on April $4^{\text {th }}, 1794$. Though Kościuszko ultimately lost his bid for Polish independence, his enlightenment ideals and the popular image of his scythe-armed peasant army endeared him to many Poles in their years of partition. In 1989, Walesa came to the stage at Racławice in a horse-drawn carriage, wearing a traditional sukmana. He took the stage and sang patriotic songs, "brandishing an upright scythe." 90 At the height of the pageantry, he proclaimed the importance of voting in every Solidarity candidate, saying "It's time to replace scythes with ballots. ... Never before did so much depend on you. The job of mobilizing society

${ }^{89}$ Halina Filipowicz, "Re-Envisioning Solidarity: History, Agency, and the Politics of Performance," Theatre Journal, Vol 62, No 3, October 2010, 333-347.

${ }^{90}$ Ibid. 
is in your hands. The government has granted us pluralism.... You must join the effort to build a new Poland, or else a new Poland will be built by others."91

Over twenty years after 1989, Polish memorials still focus on the important role that Solidarity played in bringing about the beginning of the negotiated revolutions of 1989. Especially important is Poland's role as the progenitor of the movement. Any attempt to claim otherwise can be greeted with hostility, as in the case of a bitter 2009 article in the Krakow Post. Musing on the year's upcoming celebrations, the media outlet mockingly jibed, "CNN is working on a series about 1989 titled 'Autumn of Change,' and that's significant because, even in southern Poland, early June is hardly autumn.,92

While the IPN has been discussed, and a few examples have been given to demonstrate some of its contributions to Polish commemorations, there is a great deal more to understand about this institution that has arguably more power in Polish society than the Gauck Authority has in Germany. It did not begin life as such a monolithic structure, but was allowed to become one as political changes swept through Poland in the early part of the $21^{\text {st }}$ Century.

What motivating factors can explain the rise of IPN and its grip on official memory and commemoration more than a decade after the end of communism in Poland? Beginning in the immediate aftermath of Solidarity's success, the new government turned its attention to matters other than commemorations. Poland in the 1990s was a land in transition, hampered by a struggling economy. There was little time for the government to set aside money for commemorative programs when the economy needed to be rebuilt

\footnotetext{
${ }^{91}$ Ibid.

92 "Twenty Years On,” Krakow Post, June 3, 2009. http://www.krakowpost.com/article/1342
} 
virtually from the ground up. A focus on the economy was not the only factor in keeping the government from remembering the past. There was also the matter of state-building to cope with. Poland of the 1990s was very much following Tadeusz Mazowiecki's policy of drawing a "thick line" between the communist past and the democratic present. ${ }^{93}$ There would be no time to remember, only to rebuild. The antithesis of this theme was what PiS would seize upon when they came to power in 2005.

Poland was a country that had not experienced democracy since the 1920 s, nor a sovereign government since 1939, and many of its Sejm and Senat members had never held elected office, let alone positions of national prominence. The newness of the government meant that there was a natural learning curve that had to be dealt with. Likewise, the electoral system was imperfect at best. In the October 1991 elections, the fractious nature of the new democracy led to the election to at least one seat for members of twenty-nine different parties. ${ }^{94}$ Turnout in that election only reached 43.2 percent. ${ }^{95} \mathrm{~A}$ characteristic of these early elections was also the number of "wasted votes," votes cast for a party that did not gain a seat in the parliament. In 1993, this number was an astonishingly high 34.9 percent. ${ }^{96}$ The difficulty of the electoral system led to a number of changes over the decade, with the government cycling through a variety of voting methods before finally ending with a system which reasonably eliminated wasted votes while allowing for a proportionally representative system, though there was a natural conglomeration of factions over time resulting in fewer but more powerful political

\footnotetext{
93 Poczykowski, "Building The Past," 23.

94 Ewa Nalewajko and Wlodzmierz Wesolowski, "Five Terms of the Polish Parliament, 1989-2005," The Journal of Legislative Studies, Vol. 13, No 1, March 2007. p 65.

${ }^{95}$ Ibid, 65.

${ }^{96}$ Ibid, 67.
} 
parties. Amongst these parties was PiS, the right-wing party headed by the Kaczynski brothers, which gained its highest prominence and greatest success at the ballot box in 2005, earning control over both the presidency and parliament. It was the PiS government that would successfully utilize the IPN in its campaign to rewrite memory of the Communist era in Poland as a period of victims and perpetrators, assuming what is called the "prosecutor's attitude," most meaningfully expressed in its "Fourth Republic" ideology. ${ }^{97}$ The PiS government represented the zenith of public attempts to commemorate 1989 and establish a unified national memory. ${ }^{98}$

The PiS platform was also indicative of another problem that had plagued Polish politics since the Walesa presidency; that is, the specter of Solidarity's post-Communism "war at the top."

Solidarity's enormous influence on modern politics is incontrovertible. Apart from Kwasniewski, every Polish president since the beginning of the Third Republic has claimed Solidarity ties, as do many other prominent politicians. Solidarity's struggle against the Communist regime impacted the rest of Europe and still stands as a testament to what can be accomplished by the power of a united populace. Yet in Poland, Solidarity's legacy is still being shaped. The extraordinary circumstances of Solidarity's formation are in part to blame for this predicament. As a political unit, Solidarity was created not by one core demographic, but by multiple groups, frequently with competing special interests. How it managed to overcome these differences is due to its main

\footnotetext{
${ }^{97}$ Poczykowski, Building the Past, 26.

98 The Museum of the Warsaw Uprising, created while Lech Kaczynski was mayor of Warsaw, was a popular edifice that demonstrated the popularity of the concept of national heroism. This was perhaps a forerunner to the Kaczynskis' bid to refocus national memory during the PiS government later on. http://www.1944.pl/about_museum/about_us/
} 
mission of achieving "negative freedoms," or the freedom from something rather than the freedom of something. The united goal of overthrowing the Communist power structure was more important at the time than gaining specific freedoms, thus Solidarity managed to supercede the separate interests of its left and right wings.

The sudden victory of Solidarity in the 1989 elections almost immediately changed the political landscape in Poland. Once it was assured that Solidarity would be allowed to seat its members in Parliament, and once the transition to power by the nonCommunist government was firmly in place, the need to maintain the unity of Solidarity was no longer a political necessity. Walesa immediately initiated his "war at the top," alienating the left of the party, the intellectuals such as Prime Minister Tadeusz Mazowiecki and Adam Michnik, from the right of the party, those who took a strongly pro-Catholic, nationalistic stance.

Rather than cementing Solidarity's legacy, this schism had the effect of muddling Solidarity's status in Polish historical consciousness. It was no longer a purely positive force in recent Polish memory. Even Walesa, the Nobel Prize recipient, had his legacy tarnished. According to Susan Pearce, "When asked who is the greatest figure in Polish history, Walesa tops the list. When asked who is the worst figure in Polish history, Walesa again tops the list." ${ }^{, 99}$ The fractious relationship between the former allies led to conflicting narratives Solidarity's memory, which would not be fully explored until years after 1989 , due to the struggle to reform the economy and the victory of the post-

\footnotetext{
${ }^{99}$ Susan Pearce, "The Polish Solidarity Movement in Retrospect: In Search of a Mnemonic Mirror," International Journal Of Politics, Culture \& Society 22, no. 2 (June 2009), 172.
} 
Communists in elections in the 1990s, who simply did not wish to remember the impact of Solidarity in dismantling Communist Poland.

The inability of Solidarity to maintain its cohesion led to a long period of public silence in terms of remembering modern Polish history. Because of this, there was little in the way of major public demonstrations celebrating the collapse of Communism. Instead, the citizens and leaders of towns and cities carried out memory work at the local level. Most of this memory work took the form of changing street names and dismantling Communist era statuary.

The existence of Soviet war memorials was a virtual memory minefield throughout Poland, from urban centers to rural communities. Despite the early lack of government uniformity in creating a policy to address memory and commemoration, “Solidarity's electorate was demanding a dramatic change to the urban landscape that would reflect the rapid post-communist transformation which was taking place in the country." ${ }^{\prime 100}$ The successful local government reforms gave them power and the elections of May 1990 gave local leaders the impetus to quickly address or correct memory issues in their own communities, which meant that the Soviet war memorials, of which it seems every city had at least one in a prominent location, were the most obvious candidates to receive major concentration. This particularly meant the destruction of the monuments, which most Poles did not hold in very high esteem. There were some cases in which the destruction of monuments did not occur as a result of the actions of the local

${ }^{100}$ Ewa Ochman, "Soviet War Memorials and the Re-construction of National and Local Identities in Post-Communist Poland," Nationalities Papers 38, no. 4 (July 2010), 514. 
governments, but instead due to acts of "clumsy dismantling" through "the condition of the monuments or acts of vandalism."101

Interestingly for the fate of the Soviet monuments, those that tended to be destroyed were usually the political monuments that held some prominent location with the city. Another type of monument, those which memorialized not the Red Army as a liberating force, but the individual Red Army soldiers, were frequently left untouched or relocated elsewhere. In the case that such monuments were erected in Red Army graveyards, the monuments were often allowed to remain in place. In 2007, when memory politics was in its full swing in Poland, a debate arose in an effort to decide the fate of any remaining Red Army memorials. During the debates, "the Polish heritage of Christian faith and traditions was invoked to question the initiative of relocating the remaining Red Army monuments." ${ }^{102}$ The Bishop of the Polish Army, Archbishop Slawoj Leszek Glodz, "appealed for respect and honour for the dead soldiers, stating that 'any soldier's blood has one color and one price." ${ }^{\prime 103}$ Even PiS, whose platform centered on Polish nationalism and was inherently opposed to positively remembering the exploits of Red Army soldiers in liberating Poland from German occupation, took a stance that called for moderation in the case of Red Army monuments. It "tried hard to disengage the issue of the removal of the monuments from the issue of the fallen soldiers" and claimed

\footnotetext{
${ }^{101}$ Ibid, 514.

102 Ibid, 519; Katrin Van Cant, "Historical Memory in Post-Communist Poland: Warsaw's Monuments after 1989," Studies in Slavic Cultures, 93. Van Cant also mentions the difficulties that arose over relocating Soviet war cemeteries and their monuments. Perhaps more monuments would have been removed had former Communists not raised concerns over the desecration of cemeteries.

${ }^{103}$ Ochman, War Memorials, 519.
} 
that there were "no plans to remove any monuments from cemeteries." 104 PiS based this policy on of its strongly Polish Catholic tradition that emphasizes a strong respect for the dead, though its critics attempted to claim that PiS would in fact destroy the monuments. ${ }^{105}$

The tendency towards destruction of Communist monumentalism was coupled with a focus on national ideological renewal in the form of erecting new and preCommunist monuments, often reusing the bases of very Communist monuments that were being replaced. An effort to replace the Communist monuments with new nonCommunist ones was an act of redefining new memory structures. Constructing new monuments on the bases of old ones "was needed to complete the act of obliteration," thereby symbolically removing the Communist hold over public spaces. ${ }^{106}$ Erecting the new monuments also provided a "focal point for commemorations...the key factor behind the erection of new monuments."107 Additionally, reuse of the monumental base did not permanently erase the old monument. Instead, "the signs of erasure became permanently visible and opened to future interpretations."

The national capital, Warsaw, was perhaps the most prodigious creator of new monuments in the post-Soviet era. After the destruction of most of Warsaw during the Second World War, Warsaw presented itself to the Soviets as a blank canvas, ripe for reconstruction as a model city in the Communist East. Its new buildings were dedicated

\footnotetext{
104 Ibid, 519.

105 Ibid, 520. Removal of the monuments by this time would have in any case been rendered politically difficult due to "Polish bilateral agreements regulating the treatment of war graves."

106 Ibid, 514.

${ }^{107}$ Ibid, 514.

108 Ibid, 514.
} 
to the notion of function over form, and perhaps its most famous building also became its most famous monument, the Palace of Culture and Science, a massive tribute to Socialist Realist architecture that mirrored the Seven Sisters of Moscow. Following the end of Communism in 1989, Warsaw again became the target of reconstruction, though on a different scale. New building projects were undertaken, but since the city had not been leveled as in the case of post-war Warsaw, much of the reconstruction came in the form of monuments. In the words of Katrin Van Cant, "monuments are highly fitting and representative in the project of reconstruction because, more so than books and other written historical publications, they are the first point of contact with history for an average Pole or typical foreigner/tourist."

Like the rest of Poland, which had seen over two thousand Soviet monuments and plaques removed post-1989, Warsaw saw the destruction of eleven statues between 1989 and 1998. ${ }^{110}$ To counterbalance the destruction of old monuments, and to begin a new period of reconstruction in the history of Warsaw, a massive campaign of new monument construction began in the capital. Between 1989 and 2006, a total of seventy-six new monuments were raised. ${ }^{111}$ Continuing to mirror the rest of the country, the monuments in Warsaw often tackled a very specific set of subjects. More often than not, the subjects of Warsaw's monuments were individual Poles of groups of Poles from history, with few

\footnotetext{
${ }^{109}$ Van Cant, Warsaw's Monuments, 90.

${ }^{110}$ Ibid, 91-92. Most of these statues were of important (often hated) Communist leaders. The first to be removed in November 1989 was the statue of Feliks Dzerzhinski. In 2001, the site was reused as a home for a statue to $19^{\text {th }}$ century romantic poet and "Polish bard" Juliusz Slowacki. "The replacement of the hated [Dzerzhinski] by a generally accepted 'Polish hero' can be regarded as a way of permanently settling scores with the past. The old memory had not only been removed, but had also been replaced by a new personal one." Ibid, 106.

${ }^{111}$ Ibid, 95-97.
} 
exceptions no later than the Second World War. All of these Poles were considered to be national heroes who helped defend the Polish nationality or in some way fought for independence. Not surprisingly, then, most of the historical Poles came from times when Poland was either partitioned or under wartime occupation, times with a negative connotation. The number of statues dedicated to periods that had positive connotations, like the First World War, after which Poland gained independence and established the Second Republic, is relatively small. ${ }^{112}$ This dichotomy between the perceptions of actual successes and periods of Polish oppression gives credence to an internal belief of Polish martyrdom, an idea that figures prominently into the political platform of right-wing parties, particularly PiS, whose ideology centers around heroic but tragic Polish struggles, like the Home Army's fight against the German war machine, and derides genuine political gains, like the Round Table Negotiations.

The very first monument to be erected in Warsaw following the June elections was the Memorial to the Warsaw Uprising Heroes, based on a subject that had long been taboo under the Communist government. In fact, the general suppression of memory of the activities of the Home Army in defending Poland during the war led to a great resurgence in its post-1989 memory, with almost $30 \%$ of all new monuments dedicated to the Second World War and the Home Army. Oddly, perhaps, is that the second monument to be constructed in 1989 was dedicated not to a Pole, but to George Washington. This monument was erected in time to greet the visit of President George

${ }^{112}$ Ibid, 98. Only five statues (6.5\% of all total monuments) reflect World War I. This is not to say that WWI was a wholly positive experience in Poland; indeed, the tripartite partition made the war more complicated in Poland than in other areas of Europe. It is fair to say, though, that the ultimate outcome of the war was positive for Poland, since it was finally granted independent status. 
H.W. Bush to Poland, and was erected in gratitude to American support to Poland during the 1980s and its acceptance of "Polish political refugees." $" 113$ Another American enjoys memorialization in Warsaw. A statue to Edward M. House, an adviser to Woodrow Wilson, was re-erected in 1991, forty years after Communists tore it down. House was "a noble spokesman for the Polish cause," and played a role in helping Poland achieve its independence in the wake of the First World War. ${ }^{114}$

In the seventeen-year window between 1989 and 2006, when a survey was made of Warsaw's new monuments, one prominent period has been largely neglected. In keeping with the tendency to memorialize heroic deeds during times of oppression Polish history rather than times of peace or freedom, no monuments were erected to memorialize 1989. Anti-communist monuments exist, primarily in the guise of memorials to victims of Stalinist persecution, but statues with more positive connotations, particularly of 1989 , were non-existent in the capital at this time. Of the many prominent Poles actively fighting Communism in the 1980s who might merit memorialization only Jerzy Popieluszko, the martyred priest believed to be a victim of the secret police, was given a statue. $^{115}$

In the first decade after 1989, Poland was not a nation devoid of memory or commemoration, but the circumstances surrounding the formation of the new government and a focus on the struggling Polish economy, as well as the Polish effort to join the

\footnotetext{
113 Ibid, 110.

${ }^{114}$ Ibid, 110. The quotation is inscribed on the statue's memorial plaque.

115 Ibid, 103. Popieluszko was actually a popular figure to memorialize in the 1990s. He was honored with two statues in 1996, one in 1999. A street name and a square were also named after him. One may contend that this says more about the man's status as a martyr and a priest, both highly regarded in Polish culture, rather than his anti-Communist activities. After all, there were many other Poles regarded for their anti-Communist record who have received none of the public recognition awarded to Popieluszko.
} 
European Union, meant that there was a great divide between the government and its people in terms of how it was remembering the past, and how it wished to view its present. To be blunt, the Polish government, which was largely controlled by postCommunists for much of the 1990s, avoided the issue of remembering, especially when it came to remembering 1989, which marked the ultimate failure of the Communist regime. The people, on the other hand, had been actively remembering the past in the form of destruction and construction of monuments. However, while commemoration was being channeled into one area, Poles were choosing to codify national memory around a distant past, rather than the recent events to which they had actual individual memories. This created a memory vacuum. There was no framework for understanding the successes and failures of 1989, leaving an interpretation of the negotiated settlements to open debate. The first group that would successfully attempt to address and shape national memory of 1989 would be the far right parties, particularly PiS. Their tool for doing so would be the massive and incomparable government institution of the IPN.

Like similar institutions in former Communist countries, the IPN has its roots in Poland's necessity to have a centralized archive for the massive, unorganized collection of secret archives of the former regime. Having a central office to administer the archives would make it practical and exponentially easier for researchers and historians to begin studying files that would have been nearly impossible for them to access earlier. In this respect, the IPN is reminiscent of the Gauck Authority in Germany, and was initially imagined to serve a similar function. What sets the IPN apart from other archival repositories is the dual purpose it was given. Not only was the IPN to gather and make available the many kilometers of files from the former security service and intelligence 
agencies, but it was also given the mission of investigating and prosecuting crimes committed by the Nazi occupiers and Communist government, making its scope of prosecution crimes committed between the years 1939 and $1990 .^{116}$

The IPN was not originally intended to take on a major political function, but rather to serve as an arbiter of Polish memory. By using its vast resources, the IPN would be able to organize at the national level the memory work that had begun in Poland at the local level over the previous decade. Its nominally independent status meant that it would be able to, in theory, work free of the influence of politicians in interpreting the thousands of new files that it was now in control of. However, by 2005, right-wing politicians managed to influence the output of the IPN in a dramatic fashion, using its resources as a means to fulfill its mission of reinventing the memory of the Polish nation in terms beneficial to themselves.

It is difficult to overstate the influence of the IPN within Poland, especially with regards to its competition. The Institution operates under a budget close to 57 million Euro, which it can use to attract the top prospects away from academia and keep them in one place. ${ }^{117}$ With its own in-house publishing operation, the IPN is extremely well entrenched as the top academic publisher in Poland. Its output has been astronomical, and because it controls its own publications, its ability to control prices can vastly undercut the competition. According to Dariusz Stola, the "IPN is not monopolist, there are other

\footnotetext{
${ }^{116}$ Dariusz Stola. "Poland's Institute of National Remembrance: A Ministry of Memory?" In The Convolutions of Historical Politics, edited by Alexei Miller and Maria Lipman, (New York: Central European University Press, 2012). 49-50. To date, the IPN's archival department, which maintains a central archive in Warsaw and eleven regional archives, has collected a combined eighty-eight kilometers of files.

${ }^{117}$ Wojciech Kosc, "Far More Than an Academic Publisher." Transitions Online (November 17, 2008): 3; Stola, Poland's IPN, 53. Kosc reports the budget at 57 million Euro, Stola reports it to be 55 million Euro.
} 
institutes that provide similar products, yet its privileged dominant position in the market of recent history is unquestionable; its subsidized products (books, exhibitions, etc.) flood the market. Would anyone buy your book if a publisher offers three other books on a similar topic at half the price?"

The height of the IPN's controversial activities in lustration was confined to the Kaczynski presidency, from 2005 until Lech Kaczynski's untimely death in 2010. Prior to this period, the IPN had been active in executing its original directive, and had played a positive role in the early 2000s during the controversy following Jan Gross's Neighbors, which exposed atrocities committed by a local population of Poles against their Jewish neighbors during World War II.

Direct evidence linking the Kaczynskis to overt political manipulation of the IPN is minimal, but several critical factors between 2005 and 2010 point to at least some PiS involvement in reshaping the IPN as a tool of the far right. The first event to occur that significantly altered the IPN's purpose was the great prominence placed on its vigorous attempts to publicly denounce Poles in prominent positions who it associated with the Communist party. Though not a wholly uncommon practice in formerly Communist countries, the topic of lustration did not gain significant traction until PiS came to power. Likewise, one of the indicators of a politically motivated attempt at lustration was the IPN's methods in seeking prosecution against those whom it perceived to be Communist collaborators. In May of 2008, for example, a judge threw out the IPN's case against nine former members of the Communist government on the basis that the institute lacked

${ }^{118}$ Stola, Poland's IPN, 55. 
evidence. ${ }^{119}$ Such a high profile instance is indicative of the fact that the IPN was willing in some cases to prosecute based on hearsay and speculation rather than hard fact. Cases like this remind one more of the political witch-hunt of McCarthyism rather than an actual attempt to dispense civic justice.

Another indicator of the IPN's increasingly political role during the 2005-2010 period was perhaps the most controversial action in the institute's history. In 2009, using access to the IPN's mass of internal SB files, IPN historians Slawomir Cenckiewicz and Piotr Gontarczyk published a scandalous book accusing Lech Walesa of collaboration with the secret police in the 1970s. Reaction to the book was fierce. It had its notable defenders, including Anna Waltenowycz, but its list of detractors included Solidarity members who had broken with Walesa after his rise to the presidency, people such as Gazeta Wyborcza editor Adam Michnik. In an open letter in support of Walesa, his defenders decried the tactics used by the IPN. In it, they claimed, "The institution which was supposed to preserve the national memory is now taking action to besmirch this memory... What we are now seeing is that the 'memory police' are applying the same hateful method used by the [Communist] secret police toward a victim of that very persecution." 120

The actions undertaken by the IPN to forge a new national memory created a similar identity perception to what occurred in Germany under the Gauck Authority. The major difference between the two is that the Gauck Authority's effect was less overt, and it did not have a prosecutorial arm attached to it. Poles were actively encouraged by the government and through the IPN to recognize themselves as members of one of three

${ }^{119}$ Graham, "Poland's Memory Crisis."

120 Ibid. 
categories: victims, resisters, or perpetrators. Incentives were offered to resisters and victims, whereas collaborators and perpetrators faced social ostracism. The IPN and its lustration bureau were the keystones of this categorization, because it controlled access to the secret security archives and the dissemination of information. Furthermore, its budget and political backing guaranteed that it would receive greater awareness than other research institutions. With its ability to reach the public and its stated goal of telling specific stories of Polish resistance, the IPN was in the position to influence national memory however its leadership saw fit. Of course, its leadership during its most active and controversial period was appointed by a right-wing government, the same government that explicitly sought a new narrative of the past, one in which they, the jilted former Solidarity members, maintained a link to Polish independent resistance, while the leftist Solidarity activists made deals with the Communists, in effect creating a new regime with the same people and "unPolish" moral values.

The true strength of the IPN lies not in its subject material - "after all, it's imposed by law," says Kosc - but rather that it has become "the dominant interpreter of the history of communism in Poland."121 With one institution holding such a lofty perch, it has held an entrenched position as an authority on commemorations in Poland for more than a decade. This might be changing, at least a little, as the PiS influence in the government and in the IPN has waned since its height, but as long as the IPN continues to hold sway as the predominant keeper of the memory of communism, it is likely to continue to be the main arbiter of Polish memory.

${ }^{121}$ Kosc, "Far More than an Academic Publisher." 
Two major factors leading to the relative lack of commemorations in the decade after 1989, namely the economy and evolving politics in the transitional democracies, are largely responsible for the failure of Poles to develop a truly coherent collective identity. The fragile state of the democracy led to a stronger focus on improving the economy first and foremost. The idea of commemorating the transition was little more than an afterthought, especially in Poland, where memories of Solidarity's legacy were still uncertain. This particular state of affairs was made certain by Walesa's war-at-the-top, which served to set previously allied factions within Solidarity against each other. The ramifications of this can still be felt today in PiS's vitriolic campaign against former collaborators. This inability to have an in-depth national discussion about the transition in the post-1989 years echoes Svetlana Boym's sentiments that, "Looking back ten years after the collapse of the Soviet Union, it becomes clear that, in spite of great social transformation and the publication of revealing documents and onslaught of personal memoirs, short-lived public reflection on the experience of communism and particularly, state repression, failed to produce any institutional change."122

This view of the past in part drove PiS's desire to institute "The Fourth Republic," an attempt to create a stronger break with the communist past and the installment of a government more closely aligned with the perceptions of a grander nationalist past. The hope was to rid Poland of the failure of Solidarity to wipe out the vestiges of the communist party, and through this attempt, "The campaign for the recovery of memory gave way to a new longing for the imaginary ahistorical past, the age of stability and

${ }^{122}$ Boym, Nostalgia, 58. 
normalcy. $" 123$ The failure of Solidarity in the eyes of the political right was that, unlike in previous revolutions, there was no glorious defeat of the ruling power. Because of this, a levee en masse was not possible. ${ }^{124}$ Communism was not defeated through abrupt, turbulent revolution, sweeping in a new power, but rather withered away over a period of years, trying to hold back the tide of change.

Equivalent to the failure of Solidarity to make a clean break with the communist regime, Poland's focus on economy over heritage in the decade after 1989 led to a feeling of resentment among some Poles that opened the door for PiS's diatribe against amoral Polish politicians. Looking at the physical landscape of Warsaw in the years following the transition and the emergence of a new capitalist system, Magdalena Zabrowska remarked, "In the wake of the often-ruthless and predatory encroachment of foreign business - what some Poles refer to as a rapacious capitalist 'colonization' of their country weakened by decades of communist economic devastation - this city seems overrun, if not besieged, by haphazardly placed specimens of 'Western' architecture.’125 Using IPN to achieve its aims by inundating the academic market with new material, PiS often acted clumsily and further widened the gap between left and right. However, by redefining the transitional period, PiS managed to start a conversation within Poland about the role of Solidarity's leadership in ending communist rule. In this

123 Ibid, 58.

${ }^{124}$ Schivelbusch, The Culture of Defeat, 9-10.

${ }^{125}$ Magdalena J. Zabrowska, "Reading Transparent 'Constructions of History'; or, Three Passages through (In)Visible Warsaw," Over the Wall/After the Fall, (Bloomington, IN: Indiana University Press. 2004) 112. 
respect it did at least change one of its goals, and so, as Lowenthal as said, "The end purified the means." 126

${ }^{126}$ David Lowenthal, Possessed By the Past: The Heritage Crusade and the Spoils Of History, (New York: The Free Press. 1996), 108. 


\section{Conclusions}

The parallels between commemorations in Poland and Germany show that there is a pattern in how former Communist countries have approached commemorations since 1989. Conversely, the differences in how Poland and Germany commemorate point to a diversity of factors that go into identity and memory formation. Though this might appear to be a contradiction, it is quite a reasonable assertion given the premise that, regardless of how identity and memory are shaped, the practicalities of commemoration will remain constant as long as a common set of political, economic, and societal factors is present.

As has been seen, Poland and Germany do have a number of similarities in their commemorative history. In both countries, commemorative efforts were relatively dormant until 2005, when Right-wing governments came to power. Tracking the swing of national politics in both countries is an interesting endeavor in itself, because Germany and Poland followed similar paths in their electoral leanings. Obviously, the transition to democracy for Poland and East Germany were markedly different. Poland, like most of the other former Communist countries, transitioned from a Communist government into a democratically elected multi-party system. East Germany, on the other hand, was the only former Communist country that did not keep autonomous status. Instead, its national government was abandoned and East Germany was absorbed into the preexisting government of its Western counterpart.

Despite this unique difference, Poland and the newly unified Germany began their democratic experiences under the guidance of leaders long-experienced in fighting communism. In Germany, it was under the traditional and long-established chancellery of 
Christian Democrat Helmut Kohl, and in Poland it was under the presidency of Solidarity activist Lech Walesa and the government of Prime Minister Tadeusz Mazowiecki. Walesa's immediate "war-at-the-top" in securing the presidency created divisions between Solidarity members that reverberate in Poland to this day.

Both governments failed to maintain the trust of the people to rebuild economies after the transition. In Germany, Kohl was abandoned in favor of the left-leaning Social Democrat Gerhard Schroeder, who Germans hoped would address the disparity between the struggling East and successful West. Poland narrowly voted for post-Communist Aleksander Kwasniewski over Walesa, signaling the end of Solidarity's role as a major player in Polish politics. In 1993, a Social Democrat and post-Communist electoral victory gave that faction power for four years. There is still a Solidarity party in Poland, but its influence is minimal. Former Solidarity activism is still considered a political trump card, but members of $\mathrm{PO}$ and PiS, as well as other parties, can claim activism, and often tout their involvement as more legitimate than their opponents. ${ }^{127}$

The reason these changes in government are important to commemorations is because they reflected Poland and Germany's shifting national attitudes. National politics was in some sense a weather vein of the cultural current. The people and ideals that led to the end of Communism became irrelevant in a matter of a few years as the practicalities of everyday life in democratic countries with struggling economies took root. Less concern was placed on commemorating the past because the present and future were very much in doubt. This is especially clear in Poland where little effort to officially commemorate 1989 was made. As has been discussed, there was a secondary factor

${ }^{127}$ PO, or Civic Platform, is the current center-right ruling party in Poland. 
limiting public commemorations in the years following 1989, and that was the reluctance of the post-Communist government to positively remember the collapse of Communism. More of an effort to commemorate was made in Germany. The Gauck Authority, especially the second task force in 1995, expressed desire to see a federal bureau established to handle remembrance of the whole Communist era. This ultimately came to little fruition. For the most part, commemorations were confined to the public art installations of the Übergang competition and the subtle but powerful influence of research undertaken within the Gauck Authority. It was not until several years later that either country would see resurgence in popular interest in commemorating the break with Communism.

Things changed in Poland in 1997 with the act on lustration and later birth of the Institute of National Remembrance. Initially its goal was to serve as the record keeper of secret police archives and as the arbiter of national remembrance of the Communist era, similar to the goals of the Gauck Authority, which served as its model. However, by 2005, when the Right came to power in government in the form of the Kaczynski brothers and PiS, the IPN saw a dramatic shift in its goals. Fighting back against what it saw as the moral decline of post-Communist Poland, PiS managed to use the IPN as an instrument to publicly denounce perceived former security service officers and collaborators and keep them from holding public positions.

The power of IPN and its newly established lustration bureau wielded incredible influence, especially in the academic realm, where its ability to publish under its own publishing house meant it could produce research at great quantities for lower costs, equating to a quasi-monopoly in the field of Communist remembrance. This resulted in 
spectacular claims, the most infamous of which was a book denouncing Lech Walesa as Agent Bolek, a secret police informer active in the 1970s. The aims of PiS at this time were to cast aspersions on the post-Solidarity Left and those that it felt had betrayed Poland. They believed that the Round Table Negotiations had not led to a clean break from the Communist regime, but rather allowed communists to retain power in a bargain with left-leaning Solidarity members.

Though PiS quickly lost power, its influence in using the IPN as a tool to create a new memory of 1989 has shaken the Polish political establishment. To some in Poland, Solidarity's legacy has been permanently tarnished, and divisions between parties grow ever deeper. PiS and the IPN willfully segregated Polish society into victims and persecutors, innocents and collaborators, and used Polish nationalism and the claim of morality as political tools. This dichotomy has recently come to the front again as the Polish newspaper Rzeczpospolita published an article last year indicating that traces of explosive chemicals may have been found on the aircraft that killed President Lech Kaczynski in April 2010. ${ }^{128}$ Though military prosecutors denied these accusations, saying that no such chemicals have been found, and indeed earlier inspectors at the site conclusively blamed human error as the cause of the crash, the Polish right-wing opposition has been quick to label the findings as proof of a cover-up of an assassination of the former president.

The Gauck Authority never wielded quite the same amount of power as the IPN, nor was it ever intended to. Yet its findings were still influential, and worked their way

${ }^{128}$ Monika Scislowska, "Lech Kaczynski Death: Explosives Find on Polish President's Plane Crash Denied By Government," Huffington Post. Oct 10, 2012. http://www.huffingtonpost.com/2012/10/30/lech-kaczynski-death-explosives-planecrash_n_2045030.html 
more subtly into German consciousness. The Übergang art installations of the 1990s were very much in tune with German attitudes towards reunification at the time. It was recognized as a transitional period that would require much introspection. But by 2005 , when Hildebrandt's Freiheitsmahnmal and Checkpoint Charlie Museum were in full swing, it became clear that there was a very vocal opposition to the earlier remembrance of the transition. The workings of the Gauck Authority had played a role in this change.

By only focusing on the crimes of the Stasi, that is to say the most sensational elements of the secret police, and not everyday life in the GDR, the Gauck Authority was slowly separating German people into the same categories that PiS used for Poles: victims and perpetrators, innocents and collaborators. Further complicating matters was the inability to access similar West German files, which while likely less inflammatory, would have at least given a basis for comparison. Instead, the Gauck Authority was able to give the world the worst possible impression of the GDR, that its people lived in a persistently heightened state of paranoia and terror, always one step from danger. There is no question that the security apparatus of the GDR was frightening and for good reason, but the interpretation handed down by the Gauck Authority ignored the complications and normality of life in the GDR, and in the process refashioned the arc of German collective memory. The very concept of collective memory is a broad subject, indeed, but a discussion of commemorations in Germany and Poland has helped to establish the bridge between what societies remember and how that results in identity formation.

Commemorations of 1989 in Germany and Poland are a critical part of the answer to the question of what identity those people will ascribe to themselves in the post- 
Communist world. The lack of consensus that Pearce has argued is an important part of collective memory left a noticeable gulf in Germany and Poland in the immediate post1989 period. The lack of commemorations from this period are indicative of the fact that Germans and Poles were reluctant to remember the transition. This is in part for economic and political factors, as has been seen, but it also derives from the fact that Germans and Poles were unsure how to remember their past. Without one major, collective framework on which to pin their identity, they were left with a memory void.

In Germany, Übergänge directly addressed the issue of variances in memory, providing a thoughtful look at all lives on either side of the Berlin Wall. However, the Gauck Authority would gradually change that state as its development of the perception of the GDR as a nation of victims and perpetrators would gradually begin to codify German identity. Poland had nothing comparable to Übergänge, but like the Gauck Authority, the IPN, under the direction of the PiS government, attempted to fill the memory vacuum with a framework based around a narrative of victims and perpetrators. Though it had some successes, IPN also faced considerable backlash for its most outrageous charges, and failed to achieve a consensus memory. The result is a Poland still divided in its perceptions of Solidarity and the transition to democracy.

The future of commemorating the end of Communism should be interesting in both countries. Both Poland and Germany have seen major political changes towards the middle of the spectrum. In Poland, the center-right PO continues to hold power despite continued political divisiveness. One can only speculate as to what form the IPN will take next if a moderate government continues to hold sway. Germany has likewise seen a greater shift towards moderation. Conservative Chancellor Angela Merkel is still in 
office, but last year she tapped none other than Joachim Gauck, a self-described "liberal conservative," to serve as Germany's president. This power dynamic is in itself important to modern German history, because now, after more than twenty years since the end of Communism, two former East Germans hold the top positions in the German government. Germany's continued economic successes should serve to strengthen ties between its eastern and western halves, but what impact this will have on identity formation is uncertain. Perhaps time will have given Germans more perspective on their divided past, but it is also likely that any economic success could serve to reinforce the current standard narrative of Western victory, and the old victims and perpetrators stereotype.

One does not need to look too far to find the real lessons that German and Polish commemorations provide. Space has always been a crucial element in commemorations, as can be seen in Germany, and is most useful in helping societies to visualize their history, especially when dealing with the concept of historical overlap; however, it is also a certainty that meanings attributed to any space will change over time. That is why, as Poland demonstrates, space alone is not the final arbiter of identity formation. The other major factor most typified by both countries, but is best demonstrated by Poland, is the degree to which political divisiveness can shape memory. The most evocative examples of commemoration in Poland and Germany occurred when those countries were most deeply politically divided. With this established, if both countries maintain a relatively moderate course politically, and if both can enjoy a stable economy, then one might expect the thirtieth anniversary of 1989 to be a muted affair. 


\section{Bibliography}

Berdahl, Daphne. Where the World Ended: Re-Unification and Identity in the German Borderland. Berkeley: University of California Press, 1999.

“Berlin Celebrates 20 ${ }^{\text {th }}$ Anniversary of Wall's Fall.” NPR. November 9, 2009. http://www.npr.org/templates/story/story.php?storyid=120251023. (Accessed February 15, 2011).

"Berlin Wall 20"th Anniversary." CBS. November 9, 2009. http://www.youtube.com/watch?v=KiZScTuwBZ0. (Accessed February 15, 2011).

“Berlin Demolishes Cold War Memorial on July 4," Republicans Abroad International. Republicans Abroad Germany, 24 June 2005. <http://gopgermany.com/News20050624.htm>. (Accessed April 18, 2012).

Betts, Paul. “I Want My File!.” History Today. 59, no. 10 (October 2009): 34-36.

Beyer, Gerald J. Recovering Solidarity: Lessons from Poland's Unfinished Revolution. Notre Dame: University of Notre Dame Press. 2010.

Bielasiak, Jack. "The paradox of Solidarity's legacy: contested values in Poland's transitional politics." Nationalities Papers 38, no. 1 (January 2010): 41-58. Academic Search Complete, EBSCOhost (accessed July 8, 2012).

Boym, Svetlana. The Future of Nostalgia. New York: Basic Books. 2001.

Chernyaev, Anatoly. "Excerpt From the Diary of Anatoly Chernyaev." Making the History of 1989, Item \#420, http://chnm.gmu.edu/1989/items/show/420. (Accessed April 10, 2011).

Chodakiewicz, Marek Jan. "Agent Bolek." Intelligencer: Journal of U.S. Intelligence Studies. 17, no. 2. (Fall 2009). 108-110.

Crossland, David. "Fighting the Far Right: One German State's Losing Battle Against Extremism.” Der Spiegel. September 6, 2011.

Dabrowski, Patrice M. Commemorations and the Shaping of Modern Poland. Bloomington: Indiana University Press. 2004.

de Pommereau, Isabelle. "German children: What do they know about the Berlin Wall?." Christian Science Monitor, November 10, 2009., 6, Academic Search Complete, EBSCOhost (accessed January 12, 2012). 
Diewald, Martin, Anne Goedicke, and Karl Ulrich Mayer. After the Fall of the Wall: Life Courses in the Transformation of East Germany. Stanford: Stanford University Press. 2006.

Ehl, Martin. "Poland: Dirty Laundry." Transitions Online (May 18, 2009): 6. Academic Search Complete, EBSCOhost (accessed July 8, 2012).

Ewing, Jack. “A Nation Still Divided.” BusinessWeek. November 8, 1999.

Farrar, Margaret E. "Amnesia, Nostalgia, and the Politics of Place Memory." Political Research Quarterly. 64, no. 23. August 16, 2010.

Filipowicz, Halina. "Re-Envisioning Solidarity: History, Agency, and the Politics of Performance." Theatre Journal. Vol 62. No 3. October 2010.

Flam, Helena. Mosaic of Fear: Poland and East Germany Before 1989. New York: Columbia University Press. 1998.

Forrester, Sibelan, Magdalena J. Zaborowska, and Elena Gapova, eds. Over the Wall/After the Fall: Post-Communism Cultures through and East-West Gaze. Bloomington, IN: Indiana University Press. 2004.

Garton Ash, Timothy. “1989!” The New York Review of Books. 56:17. November 5, 2009. http://www.nybooks.com/articles/23232 (accessed February 18, 2011).

Garton Ash, Timothy. History of the Present: Essays, Sketches, and Dispatches from Europe in the 1990s. New York: Random House. 1999.

Garton Ash, Timothy. "Not 1989. Not 1789. But Egyptians can learn from other revolutions." Guardian.co.uk, February 9, 2011. http://www.guardian.co.uk/commentisfree/2011/feb/09/egypt-can-learn-from-

europe-revolutions (accessed February 10, 2011).

Garton Ash, Timothy. The Magic Lantern. New York: Random House, 1999.

Gedenkstätte Berliner Mauer. http://www.berliner-mauer gedenkstaette.de/en/download/english.pdf. Accessed June 18, 2012.

Graham, Colin. "Poland's Memory Crisis." History Today 58, no. 11 (November 2008): 5-6. Academic Search Complete, EBSCOhost (accessed October 14, 2012).

Halbwachs, Maurice. The Collective Memory. New York: Harper \& Row. 1980.

Hobsbawm, Eric and Terence Ranger, eds. The Invention of Tradition. Cambridge: Cambridge University Press, 1983. 
Hogwood, Patricia. "'How Happy are You ...?' Subjective Well-Being in East Germany Twenty Years after Unification." Politics 31, no. 3 (October 2011): 148-158. Academic Search Complete, EBSCOhost (accessed March 26, 2013).

Irwin-Zarecka, Iwona. "Topography of Terror' in Berlin: Is remembrance of forgetting possible?." Journal Of Arts Management, Law \& Society 25, no. 1 (Spring95 1995): 17. Academic Search Alumni Edition, EBSCOhost (accessed March 22, 2013).

Kenney, Padraic. A Carnival of Revolution: Central Europe 1989. Princeton: Princeton University Press, 2003.

Kennedy, Michael D. and Brian Porter, eds. Negotiating Radical Change: Understanding and Extending the Lessons of the Polish Round Table Talks. Ann Arbor: Center for Russian and East European Studies, 2000.

Kosc, Wojciech. "Far More Than an Academic Publisher." Transitions Online (November 17, 2008): 3. Academic Search Complete, EBSCOhost (accessed October 14, 2012).

Krenz, Egon. "Memorandum of Conversation Between Egon Krenz, Secretary General of the Socialist Unity Party and Mikhail S. Gorbachev." Making the History of 1989. Item \#435, http://chnm.gmu.edu/1989/items/show/435. (Accessed April 10, 2011).

Levinson, Sanford. Written in Stone. Durham: Duke University Press. 1998.

Lowenthal, David. Possessed By the Past: The Heritage Crusade and the Spoils Of History. New York: The Free Press. 1996.

Mark, James. Unfinished Revolution: Making Sense of the Communist Past in Central Eastern Europe. New Haven: Yale University Press. 2010.

Markovits, Inga. "Selective Memory: How the Law Affects What We Remember and Forget about the Past-The Case of East Germany." Law \& Society Review. 35, no. 3 (September 2001): 513-565.

Marsh, Sarah. "Former Rights Activist Gauck to Become German President." Reuters. February 19, 2012. http://www.reuters.com/article/2012/02/19/us-germanypresident-newsmaker-idUSTRE81I0RA20120219. (Accessed March 12, 2013).

Nalewajko, Ewa, and Włodzimierz Wesołowski. "Five Terms of the Polish Parliament, 1989-2005." Journal Of Legislative Studies. 13, no. 1 (March 2007): 59-82.

Academic Search Complete, EBSCOhost (accessed July 8, 2012).

“Not Quite Grown Up.” Economist. November 7, 2009. (Author not identified). 
Ochman, Ewa. "Soviet War Memorials and the Re-construction of National and Local Identities in Post-Communist Poland." Nationalities Papers 38, no. 4 (July 2010): 509-530.

Offe, Claus. Varieties of Transition: The East European and East German Experience. Cambridge, MA: MIT Press, 1997.

“Official Discusses Release of Berlin Wall Documents.” NPR. November 9, 2009. http://www.npr.org/templates/story/story.php?storyid=120251027. (Accessed March 3, 2011).

Pearce, Susan. "The Polish Solidarity Movement in Retrospect: In Search of a Mnemonic Mirror." International Journal Of Politics, Culture \& Society 22, no. 2 (June 2009): 159-182. Academic Search Complete, EBSCOhost (accessed July 8, 2012).

Poczykowski, Radoslaw. "Building The Past, Forgetting The Future: Is Poland A Historical Knowledge Based Society?." Limes 1, no. 1 (June 2008): 22-31. Academic Search Complete, EBSCOhost (accessed July 10, 2012).

Ricoeur, Paul. Memory, History, Forgetting. Chicago: University of Chicago Press. 2004.

Sarotte, Mary Elise. 1989: The Struggle to Create Post-Cold War Europe. Princeton: Princeton University Press, 2009.

Saunders, Anna. "Remembering Cold War Divisions: Wall Remnants and Border Monuments in Berlin.” Journal of Contemporary European Studies. Vol. 17 No. 1. 9-19 April, 2009.

Scislowska, Monika. "Lech Kaczynski Death: Explosives Find on Polish President's Plane Crash Denied By Government." Huffington Post. Oct 10, 2012. http://www.huffingtonpost.com/2012/10/30/lech-kaczynski-death-explosives plane-crash_n_2045030.html. (Accessed Feb. 21, 2013).

Schivelbusch, Wolfgang. The Culture of Defeat: On National Trauma, Mourning, and Recovery. New York: Picador. 2004.

“Solidarity Celebrations Moved to Krakow,” Krakow Post. May 28, 2009.

Stokes, Gale. The Walls Came Tumbling Down: The Collapse of Communism in Eastern Europe. New York: Oxford University Press, 1993.

Stola, Dariusz. "Poland's Institute of National Remembrance: A Ministry of Memory?" In The Convolutions of Historical Politics, edited by Alexei Miller and Maria Lipman, 45-58. New York: Central European University Press, 2012. 
Szabo, Stephen S. The Diplomacy of German Unification. New York: St. Martin's Press, 1992.

"Ten Years after 1989: What Have We Learned," special issue, ed. Philip G. Roeder, Slavic Review, 58:4 (Winter 1999).

"The Polish Road to 1989: The Role of American Foreign Policy," series of featured articles by Piotr S. Wandycz, et al, The Polish Review 44:4 (1999).

Till, Karen E. The New Berlin: Memory, Politics, Place. Minneapolis: University of Minnesota Press. 2005.

Trouillot, Michel-Rolph. Silencing the Past: Power and the Production of History. Boston: Beacon Press. 1995.

“Twenty Years On,” Krakow Post. June 3, 2009.

Übergänge Official Website. http://www.berlin.de/mauer/grenzuebergaenge/index/index.de.php. Accessed May 20, 2012.

Van Can, Katrin. "Historical Memory in Post-Communist Poland: Warsaw's Monuments after 1989." Studies in Slavic Cultures.

Woodard, Colin. "How a picnic led to the fall of the Berlin Wall." Christian Science Monitor, September 10, 2009., 6, Academic Search Complete, EBSCOhost (accessed January 3, 2012). 